\title{
A feldolgozott könyv
}

A „feldolgozott könyv” kifejezés nem a technológiára, hanem a tartalomra utal, és az új típusú e-könyv eltéréseit kívánja hangsúlyozni az „eredeti könyvvel” szemben, amely többnyire egyetlen szerző műve, és amelyet általában egyetlen személy gondolatainak megtestesüléseként fogunk fel. A feldolgozott könyv akkor jön létre, amikor az eredeti könyvet számítógépes hálózati környezetbe helyezzük. Egy könyv feldolgozása több mint pusztán automatizált kapcsolatok (úgynevezett linkek) beépítése a szövegbe: magában foglalja az alkotás aktusának módosulását, és arra irányul, hogy lehetővé tegye és elősegítse a könyv beilleszkedését különféle alkalmazások hálózatába. Az így feldolgozott könyv jellemzően legalább ötféle funkciót tölthet be: lehet portál, platform, önmagára visszautaló szöveg, gépi komponens, illetve hálózati csomópont. Tanulmányában a szerző többek között arra a kérdésre keres választ, hogy az e-könyv vajon maga a tartalom, vagy pedig az a készülék, ami azt megjeleníti? Esetleg mind a kettő?

\section{Szerzői információ:}

\section{J o s e p h J. Es pos it o}

Jelenleg a vegyipari kutatási eredmények globális figyelốszolgálatát ellátó SRI Consulting kiadóvállalat elnöke és vezérigazgatója. Korábban az Encyclopaedia Britannica és a Tribal Voice (egy frissen indult Internet-szolgáltató) vezérigazgatójaként dolgozott. Szakmai karrierjét a kiadóiparban a Simon \& Schuster és a Random House kiadóknál kezdte. Késôbb a Merriam-Webster (a Webster szótárak kiadója) és a Britannica menedzsereként a digitális médiumok korai prófétái közé tartozott. A Britannica kiadó Merriam-Webster leányvállalatának vezetőjeként 1990 után felgyorsította a digitális kiadványok fejlesztését. Ő kezdeményezte az elsô Internet-enciklopédia, a dijnyertes Britannica Online kiadását. A Britannica vezérigazgatójaként átformálta a vállalat egész politikáját, új elektronikus programokat és új partnerkapcsolatokat épített ki, és irányítása alatt történt meg a vállalat hagyományos üzletágainak jelentổs méretcsökkentése. Miután a vállalatot 1996-ban eladták, elvállalta a John McAfee által alapított „Törzsi hang” (Tribal Voice) nevû́ hálózati közösségépítő és kommunikációs vállalat vezérigazgatói tisztét. Számos vállalat (CUseeMe Networks, MIT Press, Navilinks) igazgatótanácsának tagja, illetve tanácsadója.

Így hivatkozzon erre a cikkre:

Esposito, Joseph J.. „A feldolgozott könyv”.

Információs Társadalom IV, 3-4. szám (2004): 207-234.

https://dx.doi.org/10.22503/inftars.IV.2004.3-4.19

A folyóiratban közölt müvek

a Creative Commons Nevezd meg! - Ne add el! - Így add tovább! 4.0

Nemzetközi Licenc feltételeinek megfelelöen használhatók. 
Jos e p h J. Es pos it o

A feldolgozott könyv*

A „feldolgozott könyv" kifejezés nem a technológiára, hanem a tartalomra utal, és az új típusú könyv eltéréseit kívánja hangsúlyozni a mindannyiunk által ismert és nagyra becsült „eredeti könyvvel” szemben, amely többnyire egyetlen szerzố mûve, és amelyet általában egyetlen személy gondolatainak megtestesüléseként fogunk fel. A feldolgozott könyv akkor jön létre, amikor ezt számítógépes hálózati környezetbe helyezzük. Egy könyv feldolgozása több mint pusztán automatizált kapcsolatok (úgynevezett linkek) beépítése a szövegbe: magában foglalja az alkotás aktusának módosulását, és arra irányul, hogy lehetővé tegye és elősegítse a könyv beilleszkedését különféle alkalmazások hálózatába. Magában foglalja a szövegmagyarázatokat, de nem korlátozódik csupán azokra. Az így feldolgozott könyv jellemzően legalább ötféle funkciót tölthet be: lehet portál, platform, önmagára visszautaló szöveg, gépi komponens, illetve hálózati csomópont. A könyvek ilyenfajta feldolgozásának egyik érdekes aspektusa az, hogy alámoshatja és veszélyeztetheti a szerzô viszonyát saját munkájához; még az is megeshet, hogy a szerző kiléte a hálózati világban ugyanarra a sorsra jut, mint a szerzői jogok. Más szóval, a feldolgozott könyv alternatívát jelent az írói mesterség - és általában a könyvek - romantikus felfogásával szemben. Nem szabad választás kérdése azonban (bár még ma is írhatnánk például viktoriánus regényutánzatokat, ha kellenének valakinek), hanem szükségképpen következik a digitális médiumok belsổ lényegéhez tartozó jellemvonásokból.

Az elektronikus könyv vagy e-könyv kétségkívül megérkezett, de még nem tudott szélesebb körben elterjedni. Az e-könyvek népszerűségének mértékével kapcsolatos optimista várakozások nem teljesültek, és sokan vitatkoznak arról, hogy egy új technológia, ami olyan nyilvánvalóan hasznos, mint a szövegek digitális megjelenítése, vajon miért nem kezdte máris felváltani a papír használatát. Lehetséges azonban, hogy az elektronikus publikációról jelenleg folyó viták eltévesztik a lényeget; lehet, hogy túlságosan egyoldalúan csak a technikára és a készülékekre összpontosítják a figyelmet (bármennyire rafináltak és sokat tudóak legyenek is ezek a berendezések), és nem hatolnak a dolog mélyére, pedig éppen ott rejtőzik az, amiért elsősorban szeretjük a könyveket. A könyvek azért fontosak számunkra, ami a belsejükben van, a miatt az üzenet miatt, amit hordoznak. Az elektronikus publikáció legtöbb fejtörést okozó kérdése nem egyszerủen az, hogy vajon egyszer majd mindannyian félredobjuke a nyomtatást a képernyő́k vagy bármiféle más megjelenítési forma kedvéért, ami akkorra elfogadott standarddá válik, hanem az, hogy az elektronikus megjelenés hogyan fog hatni arra, ami a könyveken belül történik. Az a véleményem, hogy a könyvekról alkotott jelenlegi felfogásunk naiv és nyers, és hogy az elektronikus formában megje-

* The processed book by Joseph J. Esposito; First Monday, volume 8, number 3 (March 2003)

URL: http://firstmonday.org/issues/issue8_3/esposito/index.html

Copyright (C) 2003, First Monday; Copyright (C) 2003, Joseph J. Esposito 
lenô könyvek valami gondosan megtervezett, elő-fốzött és elôre megrágott szellemi táplálékot fognak adni nekünk. A félkész ételek és az előre gyártott frizurák világához hozzáadódnak a számunkra előre feldolgozott könyvek is.

Szükség van néhány definícióra. A könyveket rendszerint fizikai csomagolásukkal azonosítják. Ez a csomagolás az egyik dimenzióban általában négy-hat, a másikban pedig hét-kilenc hüvelyknyi méretû; papírra nyomtatják; és egy (rendszerint csak egy) szerző neve van feltüntetve rajta. Az ilyen csomag tartalmát azonban szintén könyvnek hívják, és ez a fajta könyv az, amirôl itt beszélni kívánok. Amint elkezdünk egyes könyveket elektronikus formában kiadni, az egész nyomtatott csomag félresöprődik, és csupán a tartalom marad. Az e-könyv tehát vajon maga a tartalom, vagy pedig az a készülék, ami azt megjeleníti? Esetleg mind a kettő? A tartalomnak a csomagolásától való megkülönböztetésére egyes érdekelt felek az „e-szöveg” (e-text) kifejezést használják. Valóban hasznos lenne, ha többen elfogadnák ezt a konvenciót. Amiket én könyveknek nevezek, azok szövegek (ha akarom: e-szövegek) vagy tartalmak. Az így értelmezett könyv ugyanaz marad, akár egy elegáns, kemény kötésư könyvben, akár egy hálózati böngészőprogramban, akár bármilyen más formátumban - például az Adobe olvasóprogramot igénylő $p d f$ fájlokban vagy a Microsoft cég Reader programjában - jelenik meg. E szerint a definíció szerint a jövő könyve nem más lesz, mint ... könyv!

Itt meg kell jegyeznünk, hogy mihelyt elkülönítjük egy könyv tartalmát a nyomtatott csomagolásától, megszûnik annak a fogalomnak az érzékelése, amit „könyvnyi terjedelemnek" szoktunk nevezni. Egy nagyon rövid könyv általában körülbelül százhúsz oldal, ami körülbelül negyvenezer szót jelent. A legtöbb könyv durván háromszor ilyen hosszú, és azok a vaskos, érzelgốs regények, amelyekkel elnyújtózunk a strandon, még ennél is kétszerte hosszabbak lehetnek, kétszázezernél is jóval több szóval. Most éppen akkor fogalmazom ezeket a sorokat, miután kiolvastam egy körülbelül félmillió szóból álló kommersz regényt, és élveztem minden egyes szavát. A könyv konkrét megjelenése és a könyvnyi terjedelem érzékelése közötti kapcsolat azért fontos, mert a tényleges fizikai csomagolás vált annak meghatározójává, hogy mit tekintünk jól kigondolt témának vagy történetnek - csak azért, mert egy ilyen téma vagy történet kifejtése megtöltené egy könyv oldalait. Más szóval, a könyvek bekötésre alkalmas terjedelme véletlenszerúen megteremtette egy intellektuális kategória voltaképpen önkényes képzetét, vagyis ebben az esetben a médium határozta meg az üzenetet. Elektronikus formában azonban bármi megtörténhet. Egy könyv (valószínúleg jobb lenne talán inkább szövegnek neveznünk, bár ebből a kifejezésből hiányzik a „könyv” szó történelmi rezonanciája) lehet akár egymillió szó hosszúságú. Lehet ugyanakkor egy pár soros, egyszerû e-mail üzenet is: semmiféle meghatározott terjedelem nem segít eldönteni, hogy mit is tekintsünk komplett gondolatnak, és egy ilyen könyv vagy szöveg fizikai megjelenése (a számítógép képernyőjén, digitális személyi asszisztensünk homlokán vagy akármilyen más formában) teljes mértékben agnosztikussá tesz bennünket, amikor az értelmezés feladatával kerülünk szembe. Érdekes lenne elgondolkodni azon, hogy kulturális értelemben vajon mit fog jelenteni, ha elveszítjük a jól kiérlelt gondolatok érzékeléséhez eddig alkalmazott mércét, amikor ezek a gondolatok többé már nem kötődnek a tintához és a papírhoz. Ebben az esszében bármilyen terjedelmû̉ szövegre utalva egységesen a „könyv" szót fogom használni. 
I.

Mielőtt azonban szert tennénk egy feldolgozott könyvre, kell, hogy legyen egy hagyományos könyv a kezünkben, egy eredeti könyv, vagyis egy olyan kifejezési forma, ami még mentes a modern világ elbürokratizálódásától és végletes „bedobozolódásától”. Az eredeti könyv furcsán romantikus mítosz, amiről egyébként szkeptikus és a legkevésbé sem szenvedélyes emberek (elsősorban a szerzők) - eléggé el nem ítélhetố módon - nem akarnak lemondani. Az eredeti könyvet rendszerint egyetlen szerző írja, olyasvalaki, akinek Van Valami Mondanivalója. A szerző dolga az, hogy a mondanivalóját kiadja magából, hogy papíron rögzítse. Ez komoly feladat. Komoly emberre van szükség hozzá. Hogy erôfeszítésének komolyságát kifejezésre juttassa, a szerző kibérelhet egy manzárdszobát, és vállalhatja a szegénységet. A még vakmerőbb lelkek esetleg taníthatnak valamelyik egyetemen. Ez spirituális küldetés. Remélhetố, hogy a szerzô alkotása végül is be lesz csomagolva a rituáléhoz megfelelố szolgálati köntösökbe: merev, kemény kötésbe, fényes borítólappal, savmentes papírra nyomtatva és talán gyönyörúen tipografált kiadói emblémával is ellátva (a merített szélư papírért külön piros pontok járnak). Az eredeti könyv legfontosabb aspektusa azonban a hiteles atmoszférája. A szerző, az alkotó létrehozta képzeletében a könyvet. Az ilyen könyv a szerző belső életének egy darabja, amit a világ elé tár mindenki számára, hogy csodálják.

A hitelesség eszméje csalárd, ám láthatólag ellenáll minden kísérletnek, ami a kiküszöbölésére irányul. Egy ifjú gyertyahordozót talán felismerhetünk arról, hogy korai érdeklődést mutat Wordsworth költészete iránt, és bezárhatjuk a semmirekellốt a fáskamrába, hogy megjavuljon, vagy megajándékozhatjuk a hálátlan frátert Kerouac összes múveivel, kemény szavakkal dorgálva eltévelyedéséért: „Érted már? Látod, hová vezethet ez?" - ám mindez hasztalan. A szerzőnek Van Valami Mondanivalója, és a könyv az a szószék, Ahol Azt Elmondja. Ez a mítosz váratlanul is felbukkanhat. Így például ezt az esszét most egy nagy nyilvánosságot kapott plágiumbotrányt követôen írom. A plágium búne támadás a hitelesség egyháza ellen. Azzal fenyeget, hogy megsemmisíti, érvényteleníti az eredeti könyvet.

Azok, akik ismerôsek a könyvkiadóiparban, és különösen azok a kevesek, akik figyelmet fordítanak a számokra, tudatában vannak annak, hogy az eredeti könyv valójában mítosz. A pályakezdốk számára jó munkaalkalom, hogy sok olyan könyv van, amit nem egyetlen szerző, és még csak nem is egy dinamikusan együttmúködő szerzőpáros ír meg, hanem írók csapata hoz létre, mások által készített szerkezeti vázlatok alapján. Gyakorlatilag mindig ez a helyzet a kézikönyvek és a legtöbb tankönyv esetében, és ez gyakran igaz a puhafedelú sorozatok köteteire is, amelyeknek a megalkotásakor szerzőknek aligha titulálható írók légiói „töltik be” a részleteket a cselekménybe és a szereplők jellemrajzába, amit a projekt vezetôje körvonalazott. Azután ott vannak mindazok a könyvek, amelyek csak tettetik azt, hogy könyvek, csakis azért, hogy könyvesbolti forgalomba kerüljenek (a néhai Hayward Cirker, a Dover Publications kiadóvállalat megalapítója a múltban olyan ifjúsági műveket is publikált, amelyeket „könyvborítóba tett játékszereknek” nevezett). Vannak továbbá könyvek, amelyeket mások munkáiból állítanak össze, néha olyan emberek hozzájárulásaiból, akiknek a személyazonossága ismeretlen marad (például a „Darwin Awards" 
esetében).* A hírességekrôl szóló könyvek különösen cinikus támadást jelentenek a hitelesség ellen. Az ilyen könyvekben egy-egy kiváló személyiség egy kísértetként a háttérben lebegő író segítségével „mondja el” a saját történetét. Ez a „kísértet” - egy olyan csavaros fordulattal, ami szinte posztmodern kívánságbeteljesülésnek tűnik gyakran már nem is láthatatlan többé, a neve megjelenik a fényes borítón, közvetlenül a híresség neve alatt, akinek a valódi szerepe voltaképpen a marketing villámhárítóé. Az eredeti könyv mítosza azonban túlságosan is erôteljes ahhoz, hogysem zavarnák a tények. A könyv az, amit a szerzố ír. A könyv a szerzố gondolatait fejezi ki. A könyveknek van bizonyos integritásuk, abból a tényből adódóan, hogy azoknak a komoly férfiaknak és nőknek a hiteles megnyilvánulásai, akik megalkotják őket.

A hagyományos könyvnek ezt a karikatúráját azzal a céllal fogalmazom meg itt, hogy könnyebben szembeállítható legyen az elektronikus könyvkiadás jelenleg kifejlődő formáival, ahol a szerző hiteles hangja eltemetődik a referenciák és az értelmezések hálózatában. Ez a feldolgozott könyv világa, azé a könyvé, ahol a szerző eredeti megnyilatkozása utat enged a hiperlinkek, a paralinkek és a neurális hálózatoknak, továbbá mindenféle egyéb kapcsolatnak és keresztkapcsolatnak is, amivel a számítógép-tudósok előállnak. Végezzünk csak el egy Google keresést a „számítógépes nyelvészet" kulcsszóra, és sohasem fogunk többé ugyanúgy gondolni a könyvekre, mint azelőtt. A feldolgozott könyv kétféle értelemben is „feldolgozott”: az eredeti megnyilatkozás a transzformációk sorozatán megy át, mielőtt eléri a végpontot, és átesik a mikrofeldolgozás különféle fázisain is, vagyis felhasználja a számítógépek megdöbbentô képességét arra, hogy kibôvítsék és gyarapítsák az eredeti szöveget.

A jelenlegi termést alkotó elektronikus könyveket gyakran éri az a kritika, hogy csengókkel és jelzôsípokkal vannak teleaggatva - ennek hallatára egy programozó akár a fejéhez is kaphatna: „Sípok! Hogy-hogy ez nekem nem jutott eszembe!? - nalássák, emmég semmi.** A jellegzetes vonások listája formátumonként más és más (egy eszövegbe személyi számítógéppel jóval több módon belenyúlhatunk, mint egy kézben tartható, viszonylag gyengébb feldolgozó kapacitású olvasókészülék segítségével), de általában mindig tartalmaz olyan hasznos dolgokat, mint például a könyvjelzők, a kiemelések vagy a hiperlinkek, és többnyire velejár a könyvvel egy középszerú vagy inkább gyatra értelmezô szótár is. Gyakran hallunk arról a csodáról, hogy nem kell hat kötetet magunkkal cipelni a repülőgépre, amikor ugyanennyit, sốt még többet bepakolhatunk egy kézben tartható olvasókészülék (reader) memóriájába. Ez talán nem is olyan csodálatos lehetôség, mint ahogyan egyesek (egyes nem-olvasók) gondolják, hiszen senki a világon nem cipelne magával még álmában sem hat könyvet a repülőgépre (még egyetlen regényt sem lehet kiolvasni annyi idő alatt, ameddig a repülőút tart San Franciscótól New York-ig, és ráadásul mindenütt találhatók nyomtatott könyveket áruló boltok). A sokféle hozzáadott lehetőség dacára azonban a jelenlegi e-könyvek mind azzal kérkednek, hogy megőrzik az eredeti, a nyomtatott könyv szövegét és

\footnotetext{
* Az általában posztumusz elnyert Darwin díjat olyan embereknek ítélik oda, akik valamilyen elképesztố ostobasággal saját pusztulásukat okozták, megerôsítve ezzel Darwin tételét az életrevalóbb egyedek szaporodásáról, vagyis a természetes kiválasztódásról. - $A$ ford.

** Az eredetiben: "Well, you ain’t seen nothing yet." (Szándékos “suk-sükölés", szleng.) - A ford.
} 
annak szellemét is; sốt az egyik olvasókészülék úgy is néz ki, mint egy klasszikus bốrkötésú könyv! Na már most, a múlt században vajon mikor olvasott bárki is rendszeresen bőrkötésû́ könyveket? Az a csapda, amibe az e-könyvek kiadói és az olvasókészülékek gyártói is beleesnek, maga az eredeti könyvet körüllengó mítosz. Arra törekednek, hogy az e-könyvnek ugyanolyan aurája legyen, mint egy divatos nyomtatott könyvnek. Az én felfogásom szerint ez sértés a digitális médiumra nézve.

A feldolgozott könyv nem határtalan vagy végtelen, de hatalmas kiterjedésû. Nem korlátozódik az olvasására szolgáló kezes készülékekre, hanem megjeleníthetô bármilyen számítógép-képernyốn. A feldolgozott könyv legérdekesebb prototípusainak némelyikét valójában nehéz használni, kivéve személyi számítógépen, mivel megjelenítésükhöz nagy képernyőre van szükség, és makacsul ragaszkodnak ahhoz, hogy valamilyen hálózati böngészốprogram segítségével olvassuk ốket (lásd például a Reed Elsevier kiadó tudományos, múszaki és orvosi folyóirat-kollekciójának kitûnő keresôprogramját és link-rendszerét). A jövőben azonban minden bizonnyal rendelkezésünkre fog állni a számítástechnikai készülékek sokasága, amelyek közül egyesek az íróasztalra kerülnek, mások becsúsztathatók lesznek a zsebünkbe, bizonyos típusok kombinálhatók lesznek a mobiltelefonokkal, másokat pedig talán sebészileg be fognak ültetni a koponyánk tövébe. A jó hír pedig a következő: ezek mind könyveket fognak megjeleníteni. Ezek a könyvek mindenféle formát fel fognak ölelni, amit csak magukra öltöttek a könyvek a múltban, és még sokkal többet. Az alatt, hogy „mindent” a múltból, pontosan ezt értem. Ha érezni akarjuk majd a bőrkötés szagát, az is beprogramozható lesz. Ha a „Huckleberry Finn kalandjai”, vagy a „Kis Dorrit” teljes szövegére lesz szükségünk, megkaphatjuk. Olvashatjuk a „Bưn és bűnhődés” szövegét oroszul és angolul; és ami azt illeti, láthatjuk majd a kézirat pontos kópiáját is egy kis ablakban megjelenítve a képernyô valamelyik sarkában. Kritikai szövegmagyarázat? Tegyük bele azt is. A lábjegyzetben megjelölt források teljes szövege? Máris benne van. Nem számít, hogy ezeknek az adatoknak egyik vagy másik része fizikailag hol található, hogy vajon az olvasókészülék memóriájában lapul vagy az Internet valamely távoli, elốretolt bástyája ôrzi, mert mindegyik azonnal elérhetô. A feldolgozott könyv összezsugorítja az időt és a teret, és a civilizáció valamennyi dokumentumát a tenyerünkbe varázsolja. A feldolgozott könyv tehát támadást jelent a dolgok természetes ritmusa ellen; a táptalajukból gyökerestôl kitépett gondolatok világát foglalja el. A manzárdszobát felcseréltük a mikroprocesszorra.

Az eredeti könyv - amikor feldolgozott könyvvé válva új kontextusba helyeződik - nem tûnik el, hanem inkább csak levetkôzi magáról azt a légkört, ami egy élô emberi lény önkifejezését hordozza, és csupán a szövegére redukálódik. Ha ez kezd úgy hangzani, mint valami obskúrus kritikai szövegelmélet vagy irodalomelmélet, ez azért van, mert az ilyen elméletek egyes aspektusai a jövô előrejelzéseinek bizonyultak. Ezt talán fájdalmas lehet belátni olyasvalaki számára, aki ôszintén imádkozott, hogy Isabel Archer ne térjen vissza Osmondhoz, a szavak azonban szimbólumok, és ideálisan megfelelnek a számítógépek szimbolikus logikájával történố manipulációhoz. A feldolgozott könyv megmutatja, hogy Isabel Archer nem más, mint az ôt megtestesítő szavak összessége. Ettől kezdve pedig már szabadon feldolgozható. 
II.

A feldolgozott könyvnek - a színrelépéséhez szolgáló eredeti könyv szövegén túlmenôen - legalább ötféle aspektusa vagy funkciója van, amelyek átfedhetik egymást, és ezek közül egyesek mostanra jobban kifejlődtek, mint mások.

\section{A) A könyv mint portál}

Ez az e-könyveknek az a funkciója, ami a legtöbb ember számára ismerős. A könyv specializálódott portállá válik, és arra ösztönzi az olvasót, hogy rajta keresztül más információforrásokhoz jusson. Ennek a legprimitívebb formája a beépített szótárral ellátott könyv. Az e-könyvben minden egyes szóhoz hozzá lehet kapcsolni a szó magyarázatát és etimológiáját, sôt különféle kiejtési változatait is, amelyek gazdagítják az olvasási élményt. Egyes e-könyvek linkeket tartalmaznak a megfelelô nevekhez vagy hálózati honlapokhoz, ahol az eredeti témával kapcsolatos háttérinformáció megtalálható. Hiperlinkekkel ellátott lábjegyzetek segítségével egy e-könyv a saját forrásaihoz irányíthatja az olvasót, némely esetben ideértve ezeknek a forrásoknak a teljes szövegét. Az e-könyv így a szöveg értelmezését segítő adatok jóval tágasabb világára nyíló ablakká válik.

Nem tehetjük meg vajon ugyanezt szerény, alázatos és igénytelen eredeti könyvünkkel is? Egy részét megtehetjük. A nyomtatott könyvek szintén tartalmazhatnak lábjegyzeteket, bibliográfiákat és más metaadatokat (ilyen lehet például a szerző előszava, a valamely tudós által írt utószó, sốt akár az adott múvel foglalkozó kritikai eszszék gyưjteménye is, lásd például a kitûnố Norton kritikai kiadásokat). A kiadók nagy dolgokat cselekedtek a nyomtatással, és minden okuk megvan a büszkeségre. Az eredeti könyv azonban hátrányba kerül a mikroprocesszorral szemben és szinte összeomlik, olyasféleképpen, mint ami a lovakkal történne, ha egy $S U V^{*}$ mezónnyel kellene felvenniük a versenyt. A nyomtatott könyvben lehetnek lábjegyzetek, ám a feldolgozott könyv tartalmazhatja az idézetek teljes szövegét is. A bibliográfia a feldolgozott könyvben egyenértékú lehet akár egy teljes szakkönyvtárral az adott tárgykörben. A nyomtatott könyvet olvashatjuk egy jó szótárral a kezünk ügyében, de a feldolgozott könyv esetében megnézhetünk akár minden egyes szót is a legújabb nagy nemzetközi Webster szótárban (Webster's Third New International Dictionary), mindössze egy-két kattintás révén; egyes oktatási és tudományos intézmények szerencsés polgárai pedig az $O E D^{* * *}$ jóvoltából ma már tanulmányozhatják egy-egy szó mai alakjának teljes fejlődéstörténetét.

Az elektronikus portál lehetôségei azonban messze túlmennek még ezen is, és összeköthetik az olvasót speciális adatbázisokkal és online szolgáltatásokkal. Az ekönyvekben lévő bibliográfia közvetlen kapcsolatot jelenthet egy közeli egyetemi könyvtár online katalógusához, ahol meg lehet nézni, hogy egy bizonyos könyv megvan-e a gyûjteményben. A „Books in Print” olvasói, akik többnyire a kiadói iparág szak-

* SUV: A nagyteljesítményú motorokkal ellátott, négykerék-meghajtású divatos terepjáró autók gyưjtốneve. - A ford.

** OED: Oxford English Dictionary (utalás az Oxford University Press legújabb online szótárára). - A ford. 
embereiból kerülnek ki, ebból a hatalmas referenciakötetból kikereshetnek bármely címet, amit óhajtanak, és ellenórizhetik az adott könyv leltári helyzetét az ország két vezetố könyv-nagykereskedésében. Más szóval, ez a bizonyos referenciakönyv „kirakattá" vált egy üzleti folyamatban, melynek segítségével a könyvkereskedők újra feltölthetik raktári készleteiket. A feldolgozott könyv lehetőséget ad arra, hogy a könyv tartalma nemcsak olvasható, hanem egyúttal „akciósítható” is legyen.

A könyv mint portál funkció egyik fontos aspektusa, hogy aláássa az olvasási élményt, még akkor is, amikor kiterjeszti azt. Az olvasás lineáris tevékenység, és a figyelem összpontosítását igényli. A portál kapcsolatai elvonják az olvasó figyelmét a szerzô lineáris gondolatmenetétôl és más szövegekre irányítják. Az a bizonyos szöveg gazdagíthatja az eredeti könyv jelentését, de egyúttal eltereli tőle az olvasót, akinek újból vissza kell zökkennie az eredeti gondolatmenetbe, amikor visszatér az elsődleges anyaghoz. Ahogy a szerzők egyre inkább tudatára ébrednek a feldolgozott könyv lehetôségeinek, arra számíthatunk, hogy a figyelem ilyen ugrásait szem elő́tt tartva kezdenek majd írni. Talán bátorítani is fogják az ugrásokat, talán nem; esetleg meg fogják tanulni, hogy a médiumnak ezt az aspektusát is belevigyék írásaikba, éppúgy, ahogyan az audiokönyvek kiadói megtanulták, hogy hallgatóik számára speciális nyomravezető jeleket adjanak, amelyek segítik őket a nyomtatásról a hangra történô átváltásoknál. („Ez a Moby Dick Herman Melville-től, negyedik kazetta, B oldal.”)

Amit igazán érdekes lesz látni az előttünk álló években, az az lesz, hogy a szerzốk vajon elkezdik-e saját mûveiket portáloknak tekinteni, és úgy kezdenek-e majd írni, hogy egyik szemüket a könyv saját határain túlra való kiterjesztésén tartják. Ezt a nyomtatott formák esetében sohasem tehetnék meg, ez csak az e-könyvek sajátsága lesz. Egyes szerzők talán szívesebben fognak homályos utalásokat tenni a szövegeikben, tudván, hogy az olvasó egyetlen kattintással eljuthat a szómagyarázathoz. Jó lenne tudni, hogy T. S. Eliot vajon mit szólna, ha ma is élne és megláthatná „The Waste Land" címú költeményének* Ray Parker által annotált online változatát.** Másrészt az is előfordulhat, hogy egyes szerzók zokon veszik majd, hogy a homályos utalások elektronikus úton könnyen tisztázhatók. Például Ezra Pound hírhedten elliptikus költészetének lényegi tartalma részben éppen a művek obskúrus jellegében rejlik, annak a puszta nehézségében, hogy felfedezzünk bennük minden utalást, ami más mûvekre vonatkozik. (Azok, akik nem ismerik Pound költészetét, gondoljanak Elvis Costello vagy a Smashmouth együttes alluzív zenéjére). Pound "Cantos” címü eposza*** feldolgozott könyvként elveszítené nehezen olvashatóságából fakadó esztétikumának nagy részét, mivel a „hasznos” kommentárok segítségével minden utalás azonnal világosan látható lenne az olvasó számára. Ha Pound tudatában lett volna a feldolgozott könyv lehetôségeinek, lehet, hogy egészen másféle költészetet alkotott volna. Hajlamos vagyok azonban azt gondolni, hogy a feldolgozott könyv minden írást - a komoly irodalomtól a bébiszitter számára hagyott üzenetekig - Pound írásaihoz

\footnotetext{
* Magyarul "A puszta ország", illetve “Átokföldje” címmel jelent meg. "A költemény 433 verssorból áll, amelyhez a költő 191 sornyi filológiai magyarázatot fűzött. [...] A Petronius Satyriconjából vett, görög szavakkal megtűzdelt latin nyelvű mottó, a Pound-nak szóló, angolul kezdett és olaszul befejezett ajánlás, és a Pound modorában 35 különbözổ íróra célozgató, külföldi szerzôket hat nyelven idézgetô, szanszkrit szavakat is tartalmazó szöveg meglehetősen kuszának tetszik." (http://encik lopedia.fazekas. hu/ palyakep/vilag/Eliot.htm )

** (http://world.std.com/ raparker/exploring/thewasteland/explore.html)

*** Magyarul megjelent: Észak-Amerikai költôk antológiája (1966); Cantók (Párizs, 1975). - A ford.
} 
hasonlóvá fog tenni, kivéve Pound tanítványaiét, akik „perverz módon” arra fognak törekedni, hogy kifejezésmódjuk világosságával és pontosságával különböztessék meg magukat a többiektől. Az e-könyvek valószínûleg egyre sưrítettebbé fognak válni, ahogy az egyetlen kattintással elérhető magyarázó szövegek révén csökken az a szükséglet, hogy mindent pontosan jelezzünk az eredeti szövegben. Más szóval, az írás nem egyszerûen kifejezésmód lesz, hanem egyszersmind számítógéppel segített kalkuláció is. Nem mondunk sokat, ha azt állítjuk, hogy Pound, aki óriási hatást gyakorolt a modernista esztétikára, segített létrehozni azt az intellektuális nyomást, ami szükségessé tette az elektronikus kiadás kifejlődését.

\section{B) A könyv mint önmagára visszautaló szöveg}

A könyvek bizonyos módon elrendezett szavakból állnak. Ha megváltoztatjuk a szavak elrendeződését, megváltozik a könyv értelme, de egyes változások felfedhetnek valamit az eredeti jelentésból, ami korábban homályos maradt. Ezt ki lehet próbálni bármely nyomtatott ismeretterjesztô könyvvel, amely tartalmaz indexet. Olvassuk végig a könyvet anélkül, hogy egyetlen egyszer is megnéznénk az indexet. Most forduljunk az indexhez, és olvassuk el az összes címszót. Új minták fognak feltûnni. $\mathrm{Az}$ index a könyv desztillátumaként érdekes heurisztikus készülékké válik.

Mondanom sem kell, hogy a számítógépek ugyanezt jobban meg tudják csinálni. A feldolgozott könyv szinte számtalan módon indexelni képes egy könyvet, és minden egyes módszer az elsődleges szöveg más és más aspektusát fogja kiemelni. Ezt a lehetôséget élvezetesen karikírozza Italo Calvino „If on a Winter's Night a Traveller" címú könyve, amelyben egy irodalomkritikus azt állítja, hogy többé nem olvas irodalmat, hanem inkább csak a múben előforduló szavak gyakoriságát tanulmányozza, a számítógépról kinyomtatott jegyzék alapján. A feldolgozott könyv meg tudja mutatni a szavak gyakoriságát, feltérképezheti azt a „normális” használat statisztikusan meghatározott mintájával összehasonlítva, kimutathatja a standard deviációt és vizuálisan megjelenítheti az eredményt; bizonyos szavakat egyes szereplő́khöz társíthat, és felismerheti a metaforák olyan hálózatait, amelyeket esetleg még a legfigyelmesebb olvasó sem vesz észre. Ezeknek a mintáknak a kimutatásával (vagy talán pontosabb lenne azt mondani, hogy ezeknek a mintáknak az elénk tárásával, hogy láthassuk és értelmezhessük őket) a feldolgozott könyv elvégzi az olvasó munkájának egy részét. A „The Scarlet Letter” egyik olvasója észreveszi, hogy Hester Prynne keblére egy piros „A” betû̉ van varrva, majd késốbb lát egy olyan bekezdést, ahol Hester egy piros rózsákkal teli kertben sétál: a kapcsolat feltárult, az értelmezés lehetséges. A számítógép szintén „kiszúrhatja” ezt a kapcsolatot, és még sok-sok mást is, potenciálisan megmutatva nekünk valamit abból a gazdagságból, amit általában csak az újraolvasás gyönyörûségeihez társítunk. A feldolgozott könyv térbelivé tágul: a könyv lineáris elôrehaladásán túl lehetôvé teszi, hogy a különböző időpontokban történt események egyidejűleg eszünkbe juthassanak. Arra készteti az elsôdleges könyvet, hogy utalásokat tegyen önmagára.

Míg a feldolgozott könyvnek ez a bizonyos funkciója a kereskedelmi forgalomban kapható könyvek jelenlegi generációjában általában nem múködik, a kutatóintézetekben már több évtizede használatban van. (Egyébként a feldolgozott könyv szá- 
mos olyan jellegzetessége, amit ebben az esszében megemlítek, még évekig nem fog széles körben elterjedtté válni.) A szógyakoriság-számlálás felhasználását az irodalmi tanulmányok eszközeként először húsz évvel ezelőtt láttam egy kiállításon, a Modern Language Association évi közgyúlésén. Ott ABC-sorrendbe szedve mutatták be minden egyes kifejezés gyakoriságát Joyce „Ulysses”-ében, olyan módszerként, ami segítheti egy köztudottan nehéz könyv megértését. A szótárkészítôk ma már rutinszerủen dolgoznak fel nagy tartalom-adatbázisokat ezzel a módszerrel, megpróbálva elkülöníteni az új szavakat és a régi kifejezések újabb értelmezéseit. (Az utóbbihoz - az új jelentésekhez - némi mesterséges intelligenciára is szükség van, hogy a módszer hatékonyan mûködjön.) A szótárak elkészíthetốk úgy is, hogy „olvassák” önmagukat, ami jó módszer a helyesírási hibák ellenőrzésére és annak biztosítására, hogy minden szó, ami egy meghatározásban megjelenik, benne legyen a szótárban címszóként is: ez a megoldás egy jó szótár szövegét zárt hermeneutikai körré teszi. Az írók a könyveknek ezt az önmagukra visszautaló jellegzetességét legtöbbször - mint a Calvinótól származó fenti példában is - humorosan kezelik. Például David Lodge egyik regényében egy író alkotói válságba kerül, amikor meglátja valamelyik könyvét ilyen módon feldolgozva. Egyszerűen nem bírja elviselni mindazt, amit ennek segítségével megtudott önmagáról. Ebben az esetben a humor az eredeti bosszúja a feldolgozott változaton.

\section{C) A könyv mint platform}

A könyv mint platform egyszerủ vagy összetett formában jelenhet meg. Az egyszerû́ forma esetében a szövegmagyarázat rá van „pakolva” az eredeti mû ártatlan, gyanútlan szövegére. Ez természetesen nemcsak az elektronikus könyv sajátossága, a nyomtatott könyvek is gyakran tartalmaznak bőséges kritikai fejtegetéseket. A platform funkciónak ez az egyszerû formája bizonyos mértékig átfedésben van a könyv portálként betöltött funkciójával, legalábbis annyiban, hogy a kommentárok gyakran az eredeti szövegre való rákattintással érhetôk el. A magyarázó szövegnek azonban nem kell formális kritikai észrevételekre szorítkoznia; tartalmazhat például kiemeléseket valamely diák szövegéból, vagy az oktatótól származó megjegyzéseket is. Jelenleg számos vállalat tanulmányozza az egyszerủ platformok lehetőségeit. Számíthatunk a használatukhoz szükséges technikai eszközök széles körű elterjedésére, különösen (legalábbis eleinte) a felsőoktatásban, ahol sok diáktól megkövetelik, hogy hordjanak magukkal laptop számítógépet, és az osztálytermi tevékenységet sok oktató kiegészíti online kommunikációval is. A könyv platform funkciójának összetett formája azonban kissé még homályosnak tủnik. Ez egyelőre még jóval kevésbé fejlődött ki, mint a feldolgozott könyv portálként betöltött, illetve önmagára visszautaló funkciói. A köny mint platform összetett formájában éppen az ellenkező funkciót tölti be. Portálként a feldolgozott könyv más dolgokra utal; platformként viszont mintegy felhívást jelent más dolgok számára, hogy azok mutassanak rá.

A könyvek ugyanabból az okból kívánják meg, hogy rájuk mutassanak, mint amiért az emberek a figyelem középpontjába akarnak kerülni. A nyomtatott könyv esetében ez a kívánság a szúkszavúan megfogalmazott aforizmák formáját öltheti, amelyek valósággal kínálják magukat az idézéshez. A tudományos munkában az eredeti felismerések közlése egy-egy publikációt az idézetek óriási hálójának a középpontjába helyez- 
het. Ez a feldolgozott könyv rendkívüli aspektusa, és bizonyos kifejtést igényel. Az $I S I^{*}$ számszerú kimutatásokat tesz közzé arról, hogy a tudományos közleményeket milyen gyakran idézik más publikációkban. A magas citációs index állítólag azt jelzi, hogy kitûnő tanulmányról van szó, ami kedvezó fényt vet a szerzôre. Nos, a több idézet vajon csakugyan azt jelenti, hogy egy tanulmány jobb a többinél? És mit értünk egyáltalán az alatt, hogy jobb? Vagy egyszerủen arról van szó, hogy csupán széttártuk a karunkat, amikor egy igazán nehéz kérdéssel, az érték meghatározásával kerültünk szembe (ne feledjük, hogy az eredeti könyv teremtette értékról van szó), és a nehéz kérdés megválaszolása helyett - mintegy proxy-ként - az egyszerû számlálás számítógéppel értékelhetố statisztikai eszközét választottuk? Ezzel nem azt akarom mondani, hogy a feldolgozott könyvnek ez a mércéje rossz, hanem csak azt, hogy nem egészen helyes. Nem azért használjuk, mert megadja a helyes választ, hanem azért, mert könnyen elérhetố választ ad - hasonlóan a régi vicchez a fiúról, aki egy sötét utca egyik végén elveszít egy pénzdarabot, de az utca másik végén keresi, mert ott jobb a világítás.

A platform a számítógép-iparban konkrét és fontos dolog; Bill Gates annak köszönheti a gazdagságát, hogy előre látta az egyik legfontosabb platform, a Windows operációs rendszer fejlődését. Platformnak azt nevezzük, amin más dolgok nyugszanak. Ezek az egyéb dolgok (amelyeket alkalmazásoknak neveznek) alapként használják vagy „elôhívják” a platform forrásait ahhoz, hogy bizonyos feladatokat végrehajtsanak. Így például a szoftverfejlesztớknek nem kell megtanítaniuk a számítógépeket arra, hogy a színeket hogyan jelenítsék meg a képernyőn, hanem egyszerûen előhívhatják a platformba beépített képességet a színes megjelenítésre.

A könyvek világában a referenciaként használt kézikönyvek azok, amelyek a legkészségesebben rendelkezésünkre állnak, hogy platformként újjáalkossuk óket. A szótárakat ma olyan szoftvereszközökkel készítik, amelyek lehetôvé teszik, hogy „előhívhatók" legyenek bármely szóról, amely megjelenik a képernyőn: csak ki kell jelölni a szót vagy kifejezést, és egy kattintásra megjelenik a meghatározás. Az enciklopédiákat szintén használják platformként, habár ennek megvalósítása általában arra korlátozódik, hogy manuálisan hiperlinkeket illesztünk be az eredeti szövegbe, amelyek azután „elôhívják” az enciklopédia adatbázisát. A platformokról alkotott fogalmainkat azonban nem szükséges az olyan, valósággal erre született háttérforrásokra korlátoznunk, mint amilyenek a kézikönyvek. Bizonyos könyveket például eredeti formájukban alapkönyveknek szokás tekinteni. Az Interneten bármi, ami alapmúnek számít, minden leszármazottjához kapcsolatokat nyújtó anyaszövegként jelenhet meg. Amikor egy könyv az alapkönyv rangjára emelkedik, a kiadó különféle eszközöket nyújthat ahhoz, hogy más munkák számára megkönnyítse az adott könyvre való hivatkozást, $s$ ez által az eredeti szöveget platformmá alakítja át. A könyv mint platform legpregnánsabb példája a Biblia, ami platformként szolgál az egész nyugati civilizáció számára. A Biblia valódi platformként történô kiadására azonban még várnunk kell, jóllehet korlátozott szintû́ portálként már megjelent.

A Biblia platformként való kiadása nem csupán azt kívánja meg, hogy a tartalom „helyes" legyen (ami ebben a kontextusban azt jelenti, hogy a platform olyan tartalmat nyújtson, amihez más emberek bizalommal fordulhatnak), hanem egyúttal az er-

\footnotetext{
* Az ISI (Institute for Scientific Information) több ezer folyóirat figyelésével múködteti a világ mértékadónak tekintett tudományos statisztikai adatszolgáltatását. - $A$ ford.
} 
re a platformra való építkezést megkönnyítố eszközök nyújtását is feltételezi más fejlesztôk (szerzők vagy kiadók) számára. Ilyen eszközök lehetnek például metajelzések, olyan információk, amelyek segítenek meghatározni a dokumentumoknak azokat az elemeit, amelyekhez illesztjük ôket. Ezek azonosíthatják például a grafikai és tipográfiai kategóriákat („ez egy kép”; „ez egy bekezdés kezdőszavának behúzása”), a retorikai kategóriákat („ez egy bekezdés”; „ez egy új fejezet kezdete”) és a tematikus egységeket („ez egy macskákról szóló szakasz”; „ez a szakasz kutyákról szól”), még akkor is, ha a nyilvánvaló kulcsszavak („macskák”, illetve „kutyák”) hiányoznak („ez a szakasz kedvtelésből tartott háziállatokról szól”). A metajelzések súlyozhatók, ami annyit jelent, hogy fontosságuk rangsorolható. Ez a bekezdés például tartalmazza a „Biblia” kulcsszót, de a bekezdés nem a Bibliáról szól, tehát ez a szó kisebb súlyú lenne. Az irodalomelméletre utaló metajelzés nagyobb súlyt kapna, jóllehet sem az irodalom, sem az elmélet nem jelenik meg itt; a legmagasabb rangot pedig talán egy olyan metajelzés kapná, amely konzultánsok által felhasználható marketingeszközként utalna a szövegre. Megkockáztatva, hogy túl messzire próbálom kiterjeszteni a metaforát, mondhatnám azt is, hogy a könyv mint platform kiadójának nyilvánosságra kell hoznia az általa alkalmazott API (Application Program Interface) paramétereit, hogy mindenkinek rendelkezésére álljon az az illesztô felületet, ami lehetôvé teszi más szerzők és kiadók számára is, hogy az adott platformra írjanak. A platform tartalmát tehát olyan információs objektumként, olyan meghatározott és jól megragadható modulként foghatjuk fel, amely más mûvek által elôhívható.

A könyv mint platform kiterjeszti a könyv mibenlétéról alkotott hagyományos felfogásunkat, megnehezítve a hagyományos könyvek újjáalkotását vagy feltámasztását platformként való használat céljából. Ebbôl az okból kifolyólag a tartalmi platformok létrehozása érdekében jelenleg folyó munka egy része az Internet eredeti sajátosságai közé sorolható, jóllehet az ezzel kapcsolatos entitások tekintetében az üzleti kilátások még bizonytalanok. Tegyük fel, hogy egy vállalkozás újsághírek kulcsszavai szerint gyưjtött referenciaadatok halmazait produkálja. Egy olvasó, aki például egy Ariel Sharonra vonatkozó utalással találkozik, rákattinthat egy rövid cikkre ezzel a személyiséggel kapcsolatban. Hasonlóképpen, egy másik szövegben a nyersolajra vonatkozó utalás összekapcsolható az olajról és az olajiparról szóló cikkekkel. Az ezzel a vállalkozással létrehozott tartalom annyiban különbözik a hagyományos kézikönyvektôl, hogy ezt már kezdettől fogva a világháló létezésére való tekintettel tervezték meg. A cikkek rövidek és könnyen megjeleníthetôk egy ablakban a számítógép képernyőjén, s a cikkek témáit olyan kulcsszavak generálják, amelyek ténylegesen megjelentek a hírekben (eltérôen a hagyományos enciklopédiáktól, melyeknek a címszavai homályosak lehetnek azok számára, akik csak újságot olvasnak). Tegyük fel továbbá, hogy egy ezzel rokon másik vállalkozás nem új tartalmat épít ki egy platform számára, hanem a világhálón elérhető honlapok címszavainak adatbázisát fejlesztette ki. Így az olvasó - amikor a Sharonnal kapcsolatos utalással találkozik - nem egy bizonyos cikkhez, hanem néhány olyan honlaphoz juthat el, amelyek információt tartalmaznak Sharonról. Ahogy egyre több és több referenciaként felhasználható információ jelenik meg a világhálón, fokozatosan meg fog szúnni az a szakadás, ami jelenleg még fennáll az eredetileg is a háló számára készített, illetve az eredetileg valamilyen más médium közvetítésével nyilvánosságra hozott tartalom között. 
Azt hiszem, hogy a könyv mint platform kifejlesztésében igen nagy üzleti lehetôségek vannak, különösen a speciális piacok által igényelt referenciaanyagok terén. Az általános referenciamúvek - mondjuk például az Encyclopaedia Britannica újabb változatai, sokkal több és részletesebb tartalommal és atomisztikus, rövid szócikkes szerkesztési stratégiával - nagy kísértést jelentenek, de egy ilyen mú létrehozásának és „karbantartásának” költségei az egekig szöknek, és a gazdasági kilátások csüggesztőek. A vertikális piacok jobb terepet nyújtanak mind a fogyasztók, mind a professzionális felhasználók számára. A kerti virágok meghatározását nyújtó online enciklopédia például információs objektumként szerkesztve jó projekt lenne, de még jobb lenne egy kifejezetten szakszerû enciklopédiát kiadni a kerti virágok génállományáról, beleértve minden egyes növény és virág genetikai térképét, letölthetố adatfájlokkal a génsebészeti beavatkozások ösztönzésére. Üzleti szempontból az a szabály, hogy minél szûkebb a spektrum és minél szakszerübb a kiadvány, annál jobb; és még annál is jobb, ha az adatok munkaeszközként is felhasználhatóvá tett formában jelennek meg, megmutatva, hogy a szóban forgó dolgok hogyan múködnek (szemben az értelmezô megközelítéssel, ami csak azt tárja fel, hogy a dolgok mit jelentenek).

A platformként használható könyvekre fordított befektetéseik visszatérülése érdekében a kiadók különféle eszközöket fognak kidolgozni, de a helyes (vagyis a legnagyobb tôkemegtérülést biztosító) gazdasági modellt a próba-tévedés módszerével fogják megtalálni. Az alapmûvek kiadói díjat számíthatnak fel más kiadóknak azért a jogért, hogy a tulajdonukat képező alapmúvet „előhívhassák”, másrészt viszont így ha a költségeket az igénylők túl magasnak találják - az alapmú esetleg nem lesz képes megfelelố hálózatot létrehozni maga körül, s ezzel aláássa saját alapmú-státusát. A rövidtávú és a hosszútávú gazdasági nyereségek között mindig alkut kell kötni, ami újabb ok arra, hogy a kiadóvállalatok továbbra is egyre nagyobbak és nagyobbak legyenek, mivel hosszú távú terveket csak a nagy szervezetek tudnak finanszírozni. Nagyon hasonló a helyzet ma a könyvtárak világában is, különösen a közkönyvtárak vonalán, amelyekkel kapcsolatban a könyvkereskedők és a kommersz kiadók mindig is ambivalens érzéseket tápláltak. A forgalomban lévő könyvek többségét kiskereskedelmi egységeken (könyvesboltokon, kedvezményes könyvklubokon és online fórumokon) keresztül értékesítik, de a könyvtárak állományába helyezett könyvnek megvan az a potenciálja, hogy megeszi a kiskereskedelmi forgalmat. Másrészt erős bizonyítékok vannak arra, hogy a könyvtári állományok marketing mechanizmusként szolgálnak a kiskereskedelmi forgalom ösztönzésére. A kiadók tehát támogatják a nyilvános könyvtárakat, feltéve, hogy azok nem veszélyeztetik a könyvek kiskereskedelmi terjesztését. Ez viszont valójában paradoxon: ha az Egyesült Államokban valaha is kifejlesztenénk egy teljes mértékben támogatott közkönyvtári rendszert, és mindenki a polgári élet középpontjaként tekintene a helyi könyvtárakra, akkor a kiadók nem adhatnák el többé a könyveiket.

Gyanítom, hogy a platformként, illetve alkalmazásként (vagyis pusztán könyvként) megjelenő könyvek marketingje között szakadás fog kialakulni. Valószínú, hogy a platformként szolgáló könyveket a kiadóik - arra törekedve, hogy ezek mindenütt jelen legyenek, és tranzakciós költségeik ugyanakkor alacsony szinten maradjanak - a már létező célközösségekben fogják piacra dobni, például az egyetemek oktatói és diákjai, egy-egy nagyvállalat alkalmazottai vagy az adott tárgykörök iránti érdeklődés szerint szervezố csoportok számára (egy helyi sakk-klub engedélyezheti a sakkjátsz- 
mák megnyitásait feldolgozó enciklopédia terjesztését tagjai körében). Azokat a könyveket pedig, amelyek az ilyen tartalmi platformokra épülnek, mind a közösségeket, mind az egyéneket megcélozva fogják terjeszteni. A kétpályás marketingstruktúra arra fogja késztetni a közösségeket, hogy nagyobb szerepet vállaljanak tagjaik információs szükségleteinek kielégítésében, ami viszont ösztönözni fogja a tagok még intenzívebb részvételét a közösségben. Ez nem „egyetlen világ”-forgatókönyvet, hanem egyfajta közös gazdasági érdekek alapján létrejövő, „törzsi” jellegû társulást jelent.

Érdemes megemlíteni a könyv platformként betöltött funkciójának egy különös aspektusát, nevezetesen azt, hogy az ilyen szándékkal létrehozott könyvek emlékeztetnek valamelyest az önbeteljesítő jóslatokra. Egy platformként szolgáló könyv más könyvekben való elôhívása érdekében közhírré teszi megjelenését és hozzáférhetôségét, részben annak az eszközkészletnek a segítségével, amit harmadik felek számára elérhetővé tesz. Egy jó könyvet jó eszközök nélkül nem fognak gyakran igénybe venni. Remélhető, hogy egy jó eszközökkel ellátott rossz könyvet egyáltalán nem fognak így használni. Ám egy jó eszközökkel felszerelt, de csak „elég jó” könyvet valószínúleg gyakrabban fognak felhasználni, mint egy „igazán jó”, de eszköztelen könyvet. Bizonyos hálózati hatások - az adott termék vagy szolgáltatás szempontjából külsőnek számító dolgok, amelyek hajlanak az eredeti termék támogatására, sôt megerôsítésére is, ahogyan például a harmadik felektôl származó szoftverek óriási mennyisége támogatja a Microsoft cég Windows platformját - ekkor életbe léphetnek, és ezek valószínúleg erősíteni fogják az „elég jó” könyv platformrangra emelkedési törekvéseit. A Google keresốrendszer például a web-oldalakat részben a más oldalakról rájuk mutató linkek száma alapján rangsorolja, és mivel a keresôrendszerek, amelyek közül jelenleg a Google a legjobb, fontos forrását alkotják a web-oldalakhoz irányuló forgalomnak, a befelé mutató linkek nagyobb száma még több befelé mutató linket eredményez. Ez azt jelenti, hogy egy sikeres könyv létrehozása egyre inkább megkívánja annak a figyelembevételét is, hogy milyen eszközök szükségesek a tényleges igénybevétel ösztönzéséhez. Nem elég mondani valamit, úgy kell mondani, hogy mások is azt akarják majd mondani.

Mi a helyzet azonban a kiváló könyvekkel? Azokkal a könyvekkel, amelyeknek az ereje érezhető́en olyan nagy, hogy megköveteli a figyelmünk ráfordítását, annak ellenére, hogy hiányoznak belőlük a platformmá váláshoz szükséges eszközök, és ügyetlenül publikálták ôket? Ha megértjük, hogy a kiváló könyvek klubja valóban kicsiny klub, akkor azt fogjuk észrevenni, hogy a kivételes könyv megteremti saját híveinek táborát, és a hívek összeállítják körülötte a feldolgozási eszközök hálózatát. A feldolgozott, ám csak „elég jó” könyv minden erőfeszítése ellenére sem fogja tudni végül lesöpörni az asztalról a kivételes eredeti könyvet, melynek a belsố intenzitása rávilágít a számítógépes feldolgozás korlátaira.

\section{D) A könyv mint gépi komponens}

A könyvek félreneveltek bennünket. Azt hisszük, hogy a könyveket számunkra írták, azért, hogy elolvassuk óket, vagyis az a végsố céljuk, hogy eljussanak hozzánk, tehát olvasóként központi helyet foglalunk el a kultúra drámájában. Ha azonban a feldolgozott könyv megkísérli elválasztani a szerzốt saját munkájának a szövegétôl, nem 
lehetünk meglepve, ha az olvasó is hamarosan támadások kereszttüzébe kerül. A feldolgozott könyv egyik aspektusa olyan könyvek létrehozása, amelyeket arra szánnak, hogy gépek olvassák őket, s amelyek beágyazódnak a gépi folyamatokba. Csupán idő kérdése, hogy gépi olvasóközönségnek szánt könyvek jöjjenek létre. A kiadóipar mai lassú növekedését figyelembe véve könnyen meglehet, hogy az iparág jövôje ennek az új vevőkörnek a kiszolgálásában rejlik.

Az emberi kultúra olyan elemeinek (például a könyveknek) a használatával kapcsolatos kutatás, amelyek számítógépi algoritmusok részévé tehetők, már évtizedek óta folyik; ez a munka bizonyos esetekben már kiterjed egyes fogyasztói készülékekre, illetve szolgáltatásokra is. Gyakran találkozunk például az írott szöveget beszédre fordító (text-to-speech, TTS) technológiával, amikor feltárcsázzuk valamely közszolgáltatást végző intézmény telefonszámát, és egy robothang üdvözöl bennünket. A TTS olyan hangok gyűjteményének kifejlesztésével müködik, amelyeket a szóban forgó szövegben előforduló betûkhöz, illetve szavakhoz rendelve, gépi úton állítanak elô. $\mathrm{Az}$ angol nyelvben mindössze negyven ilyen hang (fonéma) van, a legtöbb TTS készülék azonban ennél több hangot generál, hogy csökkentse a szaggatottságot, ami az egyes betûk egyenkénti kiejtéséből adódik. Az egyszerúnek tûnő hangképzés mögött meghúzódó kifinomult technológia valóban elképesztô eredményeket ért el, és hajlik arra, hogy háttérbe szorítsa az általa generált lexikai tartalmat. Személyi számítógépek milliói kerülnek ma piacra, amelyekbe ez a technológia már be van építve. E-mail üzeneteinket felolvastathatjuk magunknak robothangon, ha akarjuk, aminek ugyan nincs sok értelme, ha a számítógépnél ülünk, de nagy kényelmet jelenthet akkor, amikor például éppen autót vezetünk, és nem vehetjük le a szemünket az útról - a mobil TTS már elérhető. Egy szilícium-völgyi vállalat kifejlesztett egy felolvasó készüléket vakok számára, ami csodálatos hozzájárulás a világ már meglevő médiumaihoz, mivel a kiadott könyveknek csupán egy kicsiny hányada fog valaha is elkészülni audio-könyvként (és a költségek miatt még ekkor is többnyire csak rövidített formában). A TTS kétségkívül meg fogja találni az utat ahhoz, hogy minden könyv esetében alkalmazható legyen, megadva az olvasás vagy a hallgatás közötti választás lehetôségét a feldolgozott könyvek olvasóinak. (Ami azt illeti, ez a folyamat - ahogy az olvasásra, illetve hallgatásra szánt könyvek szövegéhez való hozzájutás lehetôségei, vagyis eszközei és költségei közelítenek egymáshoz - veszélyeztetni fogja, vagy akár le is rombolhatja az audio-könyvek mai két milliárd dolláros kereskedelmi forgalmát).

A TTS fordítottja a hangfelismerési technológia, bár ez még nem jutott olyan messzire, mint a TTS. Egy hangfelismerő rendszer magában foglal egy szótárt, amely segít azonosítani a kiejtett szavakat. Egyes jelenleg elérhetố rendszerek megkívánják, hogy egy bizonyos beszélő egy ideig „oktassa” a rendszert, hogy az hatékonyan mûködni tudjon, ám az az elv, hogy egy szótárnak be kell ágyazódnia a rendszerbe, így sem változik. A hangfelismerés pontosságának tökéletesítésére alkalmazott legegyszerúbb módszer a felhasznált szókincs korlátozása. Pontosan ez történik, amikor egy automatikus hangposta rendszerrel beszélünk, amely ilyesmiket mondhat: „A sípszó után kérjük, mondja be társadalombiztosítási számát, vagy billentyüzze be azt”. Az ilyen korlátozott szókincs létrehozása egyenértékû például a szótárak rövidített, puha fedelû́ kiadásaival, azzal a megszorítással, hogy a hangfelismerési technológia követelményeit nagyrészt empirikusan határozták meg, azoknak a szavaknak a tanulmányozása útján, amelyeket a felhasználók ténylegesen kimondanak, és a szótár szókin- 
cse kiterjeszthetô, ha a felhasználók ezt kívánják. Ez a visszacsatolási mechanizmus, ami sajátosan jellemző a feldolgozott könyvre, igen gyorsan, akár egy pillanat alatt is létrejöhet. Más szóval tehát a feldolgozott könyv „tanul”, és alkalmazkodik felhasználásának aktuális körülményeihez. A hagyományos könyvek ezzel szemben - csakúgy, mint a gyémántok - örökre szólnak.

Úgy tûnhet, hogy a kézikönyvek, és különösen a szótárak előnyben vannak más könyvekkel szemben abból a szempontból, hogy könnyebben válhatnak gépi komponensekké, valójában azonban minden könyv törekszik a tökéletességnek arra a fokára, amit a gép testesít meg. Ehhez azonban soklépéses folyamat végigjárására van szükség. Vegyük például a romantikus szépirodalmat. Hogyan képzelhetjük el egyáltalán, hogy egy gépnek bármi köze lehet egy romantikus regényhez? Az elsố lépés a regény átalakítása indexek gyújteményévé, szövegelemzés révén, nagyjából úgy, ahogy fentebb az önmagára visszautaló könyvvel foglalkozó részben leírtam. Az ilyen indexek közbülsố dokumentumok, amelyek értékesek lehetnek a piacra vitelrôl gondoskodó ügynökök számára, akik kivonatolhatják belőlük a szógyakorisági listákat (vagy valami más, mögöttes textuális mintát), hogy azok segítségükre legyenek a reklámozáshoz felhasználható szövegek megfogalmazásában. A feldolgozott könyv azonban még többet is tehet. Miért csak egy romantikus regényt adjunk el, amikor eladhatunk ezret is? Készítsünk linkeket minden egyes regény indexeiben egy seregnyi olyan metaadathoz, mint például a szerző neve, a megjelenés éve, az eladási arányok és a forgalom földrajzi megoszlása! Nyerjük ki az adatokat közvetlenül az eladási helyek pénztárgépeiból, és frissítsük metadokumentumainkat valós időben! Ekkor olyan dinamikus adatbázishoz jutunk, ami elárulja, hogy egy bizonyos piaci szegmentum ízlése és hangulata percrôl percre hogyan változik. (Még ennél is jobb és több információt szerezhetnénk, ha ezeket a könyveket online olvasnák, ebben az esetben ugyanis minden egyes oldal elolvasása nyomon követhető lenne.) A reklámszövegírót akár ki is iktathatjuk, és a feldolgozott adatokkal csavarinthatunk egyet a megbízó vállalat honlapján, vagy betáplálhatjuk a dinamikus adatokat egy digitális nyomdába, ahol a marketing-brosúra szövege még az utolsó pillanatban is megváltoztatható.

A könyvek világán kívül valami hasonló már folyamatban van. A Benetton szervezete rögzíti az adatokat minden egyes ruhadarabról, amelyet eladnak, és az így létrehozott adatbázist a divattrendek megállapítása végett folyamatosan értékelik. Az értékelés eredményeit azután visszatáplálják a termelésbe, ahol befolyásolhatják a színválasztékot. Könnyen lehetséges, hogy az ingek színe a Benetton leltárában az egyik hétról a másikra megváltozik, közvetlen válaszként arra az információra, amit a pénztárgépektôl visszacsatolnak a gyártómúhelyekhez. A feldolgozott könyvek bevezetése az efféle rendszereket tovább fogja finomítani, kulturális alapon súlyozó mechanizmusokkal elôsegítve a raktári készletkezelésre és a vásárlások ösztönzésére szolgáló eljárások hatékonyságának optimalizálását.

\section{E) A könyv mint hálózati csomópont}

Az eredeti könyv különálló tárgy, a feldolgozott könyv viszont csomópont valamely hálózatban. Ma már tudjuk, mi történt az eredeti könyvvel: csomóponttá változott és akként van jelen, összekapcsolva más csomópontokkal, amelyek közül sok ma- 
ga is eredeti könyv. Hasonlítsuk ezt össze a DNS-sel! Minden egyénnek megvan a maga saját, egyedi DNS-e, de ebben a DNS-ben sok minden közös minden más emberével, akár élő́k, akár holtak, vagy - ami azt illeti - akár még meg sem születtek. Mindannyian unokatestvérek vagyunk.* És ez igaz a könyvekre is, ha olyan hálózatba helyezzük ốket, ahol mások rájuk mutatnak és maguk is rámutatnak másokra, ahol elemzik, értékelik, feldolgozzák és elosztják ôket, és ahol a könyvek feltárják tartalmukat minden más könyv számára. Amikor Hemingway megjegyezte, hogy az egész amerikai irodalom visszavezethetô a Huckleberry Finn-re, ezt a rokonságot ismerte fel. Amikor egy szövegelemzó program megállapítja, hogy egy bizonyos régióból származó írók több alárendelt mondatszerkezetet használnak, mint egy másik régió írói, akkor ez is a rokonságot határozza meg.

A hálózati csomópontok közötti kapcsolatok többszörösek lehetnek. Egy csomópont felhasználható gépi összetevőként és segítségként egy másik csomópont létrehozásában, amely platformként szolgál egy harmadikhoz, amely viszont támogatja az elsốt. A hálózati térkép megmutatja, hogy az egyes csomópontok hogyan kapcsolódnak egymáshoz, tehát voltaképpen a feldolgozott könyv arcképe és családfája: bemutatja a könyv őseit, közvetlen elődeit, leszármazottait és egész családi kapcsolatrendszerét. Ez a térkép maga is egy dokumentum (nevezhetjük esetleg ezt is könyonek?) vagy metadokumentum, amely éppen abból az erôtérból ered, amelyet leír, és viszonzásként visszahat rá, nagyon hasonlóan ahhoz, ahogyan a tudat befolyásolja egy emberi lény viselkedését.

Mindez bizonyára meglehetôsen elvont okoskodásnak tûnik azok számára, akik csupán egy egyszerû, önmagában teljes szöveget - például egy memoárt vagy egy kategóriaregényt (detektívhistóriát, románcot, tudományos fantasztikus történetet, stb.) - akarnak megírni. A probléma az, hogy az önmagában teljes szöveg gondolata a papírra nyomtatott médium terméke. A feldolgozott könyv kihívása az írókkal szemben abban áll, hogy az íróknak kettős tudatossággal kell dolgozniuk, egyrészt mint eredeti szerzőknek, másrészt mintegy átkukucskálva a saját válluk fölött, hogy láthassák a könyvet, miközben azt szinte már megírása közben is feldolgozzák. Az eredeti könyv rendőri felügyelet alatt áll. Nehéz lenne sok olyan szerzőt elképzelni, akinek a munkáját nem befolyásolja az a tény, hogy állandóan egy kamera figyeli ôket. Fontos továbbá megjegyezni azt is, hogy ez a bizonyos felügyelet nem választás kérdése. Egyes romantikus írók megpróbálják elhárítani a feldolgozott médiumok betolakodását, ám azok lesznek a legsikeresebbek, akik keblükre ölelik a hálózatot, mivel a sikert a szöveg, illetve a csomópont fennmaradása és „rámutathatósága” határozza meg.

Érdemes megjegyezni, hogy a feldolgozott könyv csomóponti aspektusának nagyon fontos gazdasági következményei vannak, amelyek a következő években valószínúleg át fogják formálni a kiadóipart. A szerzôi jogot fenyegetô veszélyek például viszszaszoríthatók lesznek. A kiadók már hosszú ideje figyelik a zeneiparban mưködő hittestvéreik megpróbáltatásait, és jobban rettegnek a szerzői jogokat érintő kalózkodástól, mint bármi mástól. A kalózkodás persze nemcsak a digitális könyvek osztályrésze,

* Az eredeti angol mondat így hangzik: „All men are cousins.” Azért választottam a szó szerint nem pontos, de tartalmilag helyes fordítást, mert a szerzô később visszatér erre a mondatra, és mondanivalójának illusztrálásához - mint látni fogjuk - ez a változat jobban megfelel, mint ha ezt írtam volna: „Minden férfi egymás unokatestvére." - $A$ ford. 
ahogy azt bármely kiadó megmondhatja, aki már utazott Ázsiában, de sokkal nagyobb mértékûvé válik, ha az Internet útján a könyvek kópiái elterjeszthetốk lesznek az egész világon. A Napster elnevezésû́ elsô tömegpiaci file-sharing szolgáltatást a zeneiparnak sikerült megnyirbálnia és visszaszorítania, a file-sharing azonban a Napster földalatti örököseinek (LimeWire, Aimster, stb.) tevékenységével és a UseNet univerzumán belül még mindig folyik. A kalózszolgáltatások sok könyvet elrabolnak ma is, és ennek hatására egyes kiadók - attól félve, hogy termékeik a file-sharing illegális világának martalékává lesznek - a digitális kópiák terjesztésétôl távol esố békésebb vizekre kormányozzák hajójukat.

A feldolgozott könyv azonban publikálható valamely hálózat csomópontjaként is, más könyvekkel létesített kapcsolatokkal, szövegmagyarázatokkal, online könyvtári katalóguskártyákkal, tanárok ajánlásaival, és így tovább. Ha a hálózatot úgy fejlesztették ki, hogy hasznos legyen (és itt fontos a „ha”, mivel az öncélú linkek és más kapcsolatok zavaróak lehetnek), akkor a könyvnek mint csomópontnak nagyon jót tesz, hogy a hálózat részévé válik. Ha az eredeti könyv eleve csomópontként készült, akkor kalózmásolatai nem fognak rendelkezni az összes hálózati kapcsolattal, s ez sokat levon a kalózkópiák értékéből. Ez tehát vissza fogja hozni az olvasókat a csomópontként funkcionáló könyvhöz, mégpedig nem az eredeti értéke miatt (hiszen a tartalom a kalózkópiákban másutt ingyen elérhető), hanem a feldolgozottságból adódó hálózati értéke miatt. Ez több kiadót bátorítani fog arra, hogy elektronikusan elérhetôvé tegyék könyveiket, feltéve, hogy rendelkezni fognak a szükséges eszközökkel ahhoz, hogy a könyveket gyorsan be tudják illeszteni a megfelelő hálózatokba.

Ehhez sok szempontból hasonló folyamat zajlik le már napjainkban is a tudományos folyóiratok világában. Mint korábban megjegyeztük, a Reed Elsevier, a szakfolyóiratok vezetổ kiadója tudományos kutatási eredményeket tartalmazó kiadványainak gyưjteményéhez nagyteljesítményú keresốprogramot épített ki. Ez nagyon agyafúrt lépés, és könnyen lehet, hogy a Reed ügyfelei (elsősorban a tudományos könyvtárak) még nem látják tisztán, hogy valójában mi folyik itt. A tudományos közösségben van egy gyarapodó mozgalom a kutatási eredmények közlési módjának megváltoztatása érdekében: sokan amellett érvelnek, hogy minden tudományos kutatást ingyenesen elérhetôvé kell tenni mindenki számára, akinek van Internet-összeköttetése. A mozgalom harcosainak szemében a Reed a legfóbb búnbak, talán némi okkal, mivel keresztülvitte számos folyóiratának agresszív áremelését. Ma sok cikk jelenik meg különféle előzetes publikációs formákban az Interneten, amelyek alááshatják a Reed folyóiratainak értékét, és megindult egy mozgalom azzal a céllal, hogy a kutatók saját maguk archiválják munkáikat, mielốtt leadnák valamely folyóiratnak (errốl a tárgyról lásd például Stevan Harnad írásait). Ez lefékezné és megállítaná, vagy legalábbis habozásra késztetné a kiadókat. Ha egy cikket a szerzôje maga archivál az Interneten, akkor azt egy hálózati böngészố programmal bárki ingyen elolvashatja. Miért folytatnák tehát a könyvtárosok a folyóiratok megvásárlását, különösen, ha az árak továbbra is emelkednek?

A Reed válasza erre a kérdésre a feldolgozott könyv létrehozása, bár természetesen ezt sohasem fogalmazták meg így, és a mögötte meghúzódó stratégiát sem hozták nyilvánosságra. A Reed keresőprogramja hozzáadott értéket biztosít az indexelt és figyelt folyóiratok számára; a kiterjedt kapcsolatháló több értéket ad a rendszerhez. A folyóiratok adatbázisához sok közérdekû dokumentumot is hozzátesznek, amelyek mindegyike egyidejûleg kereshetô. Az adatbázis nagyobb lesz, és így a jó keresőprog- 
ram iránti igény is növekszik. Most tehát bármely dokumentum értékét jelentősen fokozza, ha az része lehet a Reed által létrehozott hálózatnak. Ha ezeknek a cikkeknek a másolatait a szerzók elhelyezik a saját archívumukban, akkor az érték, amit képviselnek, csak az övék lesz, feltéve, hogy bárki meg tudja találni őket, ám csomópontként a hálózatba helyezve emelkedik az értékük. A nyilvánosan hozzáférhetô dokumentumok beillesztése különösen ügyes húzás. Azt látjuk tehát, hogy a Reed átvitte az értéket a mindenki számára szabadon hozzáférhetô dokumentumokból a keresőprogramra, erre a dinamikus metadokumentumra, ami segíti az olvasót a szóban forgó dokumentumok megtalálásában. Bizonyos értelemben azt is mondhatjuk, hogy a Reed - a „klubtagok” megkérdezése nélkül - felveszi hálózatába a nyilvános szférát. Kinek van tehát szüksége a szerzői jogra? A gazdasági kihívás a tartalom szerzői és a kiadók számára abban rejlik, hogy olyan tartalmat hozzanak létre, amely megkívánja, hogy beillesszék valamely hálózatba, illetve biztosítsák, hogy a hálózat domén-specifikus keresố teljesítménye mindig egy lépéssel az olyan általános érdekú keresőprogramoké előtt járjon, mint például a Google.

Mưködhet ez vajon a könyvek esetében is, éppúgy, mint a folyóiratoknál? Mưködhet, és múködni is fog. Mire eljutunk a Harry Potter sorozat huszonharmadik kötetéhez, az e-könyvek mindenütt jelenvalóak lesznek. Az új kötetet elektronikusan fogják publikálni, és sok mindent - például linkeket az előzố kötetek fontos részeihez és szereplôihez, egy Harry Potter-szótárat, a Harry Potter-klubok honlapjaira mutató kapcsolatokat, és még sok-sok egyebet is - bele fognak építeni. Nagy lesz a kísértés arra, hogy ellopják a szöveget, de a kalózok nem kaphatják meg a beépített linkeket például a következő filmfeldolgozás elôzeteséhez, és így a kalózmásolat már nem is lesz olyan „cool”, ahogy bármelyik gyerek megmondhatja. A kalózkodás féken tartható lesz a nagyon eredeti Harry Potter kötetek feldolgozott könyvekként való újraalkotásával ezt fogja megkívánni a kiadóipar gazdaságossága.

III.

Ki fogja megvalósítani a feldolgozott könyvnek ezeket az aspektusait? A szerzők? Az ügynökeik? Vagy van remény a kiadók, e szellemi sötétségben élô szervezetek számára is, amelyek ellopják a szerzôk lelkét?

A válasz: igen, ezek mind, és még sokan mások. A feldolgozott könyv nem egyszerú dolog, és nem is különálló, koherens rendszerként fog megvalósulni, valahányszor egy új könyvet írnak vagy kiadnak. A könyv feldolgozása szerves fejlődési folyamat lesz. A szerzők is belefekszenek a munkába, csakúgy, mint az olvasók, a kritikusok, a kiadók, a könyvtárosok és mindenki más, aki csak hozzáér egy könyvhöz. Nyilvánvalóan van hely közöttük a szoftverterjesztốknek is, továbbá a távközlési vállalatoknak, amelyek az adott tartalmat haszonnal közvetíteni fogják, függetlenül attól, hogy egy-egy bizonyos hálózati csomópont miről szól. Nem minden feldolgozott könyv teremtetik egyenlônek. Azokat a könyveket, amelyek valósággal felkínálják magukat a más szövegekkel való összekapcsolásra, jobban fel fogják dolgozni. Ki fog alakulni egy új mennyiségi mérôszám: egy könyv egyenlő lesz azoknak a dolgoknak az összegével, amelyekkel összekapcsolható, és amelyek rajta keresztül elérhetôk.

A szerzők fel fogják dolgozni saját könyveiket már az írás folyamatában, valójá- 
ban néhány éve már ezt is teszik, hiszen a szövegszerkesztés a feldolgozott könyv egyik aspektusa. A szerzők egyre inkább a feldolgozás lehetőségeinek észben tartásával fognak írni, megváltoztatva szövegeik természetét, ami tükröződni fog stílusukban, témaválasztásukban, stb.. Ahogy már most is segítenek könyveiket mások figyelmébe ajánlani, ugyanúgy egyre inkább fel is fogják dolgozni könyveiket, talán weblogok létrehozásával (lásd például www.andrewsullivan.com), ami segítheti a könyv reklámozását, és másokat arra ösztönözhet, hogy a feldolgozás újabb rétegeivel egészítsék ki azt. Ügynökeiket és kiadóikat részben aszerint fogják megválasztani, hogy azok mennyi „feldolgozottságot” tudnak biztosítani könyveik számára, mint ahogyan ma az iránt érdeklődnek, hogy kinek vannak a legjobb kapcsolatai az egyik vagy a másik televíziós talkshow producereivel.

Teljesen át fognak térni vajon az „ön-publikálásra”, és teljesen kiiktatják a kiadókat? Egyesek ezt fogják tenni, de a kiiktatás talán túlzás. Ahhoz, hogy kiépítsék az alapvetô feldolgozási kapcsolatok hálózatát, a kiadók jobb helyzetben vannak, mint az egyes szerzók. Nehéz kiépíteni és fenntartani egy önmagában álló honlapot, de ezer ilyet felépíteni és karbantartani triviális feladat. A kiadóvállalat nagyobb léptékú egzisztenciája valamennyi szerzô, könyv, illetve csomópont számára hasznos lesz, amelyek összeköttetésben állnak vele. A kiadók szoftvereszközöket fognak szerezni minden általuk kiadott kötethez, amelyek bármely szerző számára felhasználhatók lesznek. Portálok és platformok kialakítására szolgáló eszközöket fognak bevetni, továbbá olyanokat, amelyek az önmagára visszautaló, illetve a gépi komponenssé átalakítható könyvekhez használhatók fel, és végül arra is alkalmasak, hogy a könyvek hálózati csomóponttá válhassanak. Eszközeik felhasználási lehetőségeit a kialakuló értékláncban ki fogják terjeszteni az olvasókra és a kritikusokra is, akik újabb linkeket fognak hozzáadni minden egyes szöveghez. Ezt már kezdjük is látni az Amazon.com esetében, ahol minden egyes címet körülvesznek a kiadók reklámszövegei, valamint az amatốr és hivatásos kritikusok által írt recenziók. A feldolgozott könyv létrehozásának költségei miatt fontossá válik a kiadók mérete: a feldolgozott könyv hozzá fog járulni a kiadóipar folyamatban levố konszolidációjához, melynek során az egyre csökkenő számú, ám egyre növekvő kiadóvállalatok mind nagyobb piaci részesedést szereznek.

A szerzők végsố megalázásaként valószínűnek tûnik, hogy a könyvek alkotói el fogják veszíteni ellenốrzésüket a szerkesztôségi entitások fölött. Ez bizonyos mértékig természetesen mindig így volt, mivel a rossz vagy félrevezető recenziók sok könyv fogadtatását befolyásolták az évek során. A feldolgozott könyv esetében azonban mind mértéküket, mind jellegüket tekintve megváltoznak a dolgok. Egy könyv elborítva találhatja magát hozzá kapcsolt kommentárokkal, és ha ezek a kommentárok felelőtlenek, hogyan lehetne ezeket másként helyreigazítani, mint újabb kommentárok ráhelyezett rétegével? Még rosszabb (vagy jobb, az ember állásfoglalásától függően), hogy egy-egy mú különféle változatai egymástól függetlenül kerülhetnek forgalomba, és mindegyik kiépítheti a saját hálózatát maga körül. Nos, ha ezek közül a változatok közül egy vagy több nem pontosan felel meg a szerzố eredeti szándékának, ki fogja ezt megállapítani? Mi akadályozhat meg bárkit is abban, hogy bizonyos változtatásokat eszközöljön az eredeti múben (én például sohasem szerettem Desdemona szemét), mielőtt a módosított szöveget továbbítja a következô személyhez, azután a következőhöz, majd mindenkihez, és így tovább a végtelenségig? Vagy talán - pusztán annak köszönhetően, hogy minden szöveg, az összes kapcsolatával együtt, kifinomult, 
választékos és gyötrelmes részletességgel, mindenkor, mindenki számára elérhetővé válik - lesz egy Láthatatlan Kéz a kritikai szövegmagyarázatokban, amely biztosítja, hogy idôvel a „helyes” szöveg és a „helyes” értelmezés fog fennmaradni?

IV.

Tételezzük fel, hogy ez az esszé feldolgozott könyvként készült el, a megfelelő kiterjesztésekkel! Miben különbözne attól, amit önök éppen most olvasnak?

A leginkább kézenfekvố ponttal kezdve: ez az esszé máris feldolgozott könyv, bár feldolgozottságának mértéke túlságosan konvencionális ahhoz, hogy bárkinek a figyelmét magára vonja. Ez a dokumentum a Microsoft Word szövegszerkesztővel készült, amely egy szófeldolgozó szoftver (jó kifejezés!). Megszerkesztették és újraszerkesztették, körbeadták, szétszedték és kockára vágták. Jó néhányszor bejárta az Internet láthatatlan csatornáit, útban a szerző különféle barátaihoz, akik hajlandók voltak megjegyzéseket fúzni hozzá. Miközben körbeküldtem, úgy döntöttem, hogy nem fagyasztom be a szöveget $p d f$ fájlként, hanem Word formátumban hagyom, ami lehetőséget ad a szerkesztésre. Valóban, a pdf fájlok egyik állítólagos erénye, nevezetesen, hogy megakadályozzák a szöveg manipulálását, a feldolgozott könyv kontextusában hátránynak bizonyulhat, mivel a szerkeszthetetlen fájlok esetében kevésbé valószínú, hogy kommentárok hálózata épül köréjük. (A pdf technológia egyes új változatai és kiegészítései lehetôvé teszik, hogy az alapfájl változatlanul maradjon, még akkor is, ha szerkesztett változatai, köztük a szövegmagyarázatokkal ellátott verziók is megjelennek mellette). Ennek az esszének egy korai változata felkerült egy hálózati szerverre, ami idővel gyakorlati problémát jelenthet számomra: Hogyan gondoskodhatnék arról, hogy az olvasók megtalálják az utat a jelenlegi változathoz? A válasz akár jónak, akár rossznak tekintjük - az, hogy a feldolgozott könyv elkerülhetetlenül a szerzői kontroll elveszítéséhez vezet. Ez tûnődésre készteti az embert: A szerzői kontroll nélküli világban az írók vajon le fognak-e mondani arról, hogy a szerzői babérok, a hírnév kedvéért írjanak?

Most azonban tekintsük át a feldolgozott könyv öt aspektusát, és nézzük meg, hogyan alkalmazhatók erre a dokumentumra!

Portálként „A feldolgozott könyv" sok linket tartalmazna, amelyek különféle más hálózati csomópontokhoz vezetnek, ahol további információk találhatók az itt tárgyalt gondolatokkal és személyekkel kapcsolatban. Lennének linkek például további információkhoz Steven Harnadról, Alan Kay-ról és Ted Nelsonról. További linkek kapcsolódnának esetleg az esszé korábbi fogalmazványaihoz, beleértve talán azt a sok e-mail üzenetet is, amelyeket azoktól az emberektôl kaptam, akik megjegyzéseket füztek hozzá - nem mind kedvezốen. Az említett Google keresést a „számítógépes nyelvészet” címszóval végrehajthatnánk a szövegen belül: csak egy kattintás, és máris megjelenne az eredmény.

Az esszé már eddig is szolgált ideiglenes portálként egy bizonyos olvasó, egy régi barátom számára, aki alaposan végigolvasta. Eközben találkozott az Isabel Archerre és Osmondra való utalásokkal, akikről azelốtt még sohasem hallott. Így tehát a Googlehoz fordult, és hamarosan javában olvasta Henry James „Egy hölgy arcképe” című regényét, melynek főszereplője, Isabel hozzámegy az ármánykodó Osmond-hoz. Miért nem voltak megmagyarázva ezek az utalások a szövegben? Ennek több oka van. Elő- 
ször is, abban a társaságban, ahol rendszerint forgok (a keleti parton) szinte mindenki tudja, ki volt Isabel Archer, bár például a Calvino könyvére tett utalás kétségkívül több magyarázatot igényelne. Az ember azonban sohasem tudhatja pontosan meghatározni egy-egy bizonyos olvasó múveltségi körét, hiszen végtére is nincs olyan általánosan elfogadott kultúra, amire támaszkodhatnánk, nincs sziklába bevésett kánon: egy olyan világban, mint amilyenben ma élünk, a feldolgozott könyv a kulturális egységesülés eszközévé válhat. Az egyik olvasó számára (a nyugati parton) Isabel Archer rejtélyes lehet, míg egy másik számára (a keleti parton) a bayesi statisztikából levezetett algoritmusokra való utalás lehet rejtély. Az írónak mindezekkel a lehetôségekkel számolva kell dolgoznia, s éppen ezért szükségszerű a feldolgozott könyv mint portál megjelenése. Isabelt egyébként szándékosan nem magyaráztam meg a szövegben, mert tudtam, hogy vissza fogok térni rá, amit éppen most teszek meg, tehát az utalást tudatosan kissé homályosra formáltam, éppen abból a célból, hogy demonstrálhassam a könyv mint portál szükségességét. Úgy döntöttem, hogy az esszét a saját felügyeletem alatt írom meg.

A könyv portálként betöltött funkciója idővel meg fog erősödni. Az csak egy lehetőség, hogy bizonyos kulcsszavakra (például tulajdonnevekre) a Google segítségével rákereshetünk, ám bizonyos célzások és utalások értelmezése még így is jelentôs kihívást jelent. Az esszé szövegében korábban előfordult ez a mondat: „Mindannyian unokatestvérek vagyunk.” („All men are cousins.”) Mit kezdhet ezzel egy keresőprogram? A mondat tartalmát, mondanivalóját a figyelmes olvasó azonnal felfogja és úgy értelmezi, hogy „minden ember testvér” (all men are brothers). A Google azonban erre a mondatra rákeresve ilyesféle „találatokat” is hozna: „minden ember disznó” (all men are pigs), „minden ember söpredék” (all men are scum), „minden ember egyenlőnek teremtetett” (all men are created equal). Lehet, hogy egyesek számára mindezek a kifejezések egyenértékúek. A figyelmes olvasó azonban azt is megfigyelheti, hogy ebben az esszében a "mindannyian unokatestvérek vagyunk” (all men are cousins) kifejezés* az egyetlen, ahol úgynevezett „szexista” terminus fordul elô. Az efféle vádak ellen azzal tiltakozhatnék, hogy rosszul hangzott volna, ha szaporítom a szót és azt mondom, hogy „mi mindannyian, férfiak és nők, unokatestvérek vagyunk” (all men and women are cousins), és ez elhomályosította volna a "mindannyian fivérek vagyunk” (all men are brothers) kifejezésre való burkolt utalás többrétegû üzenetét. ${ }^{* *}$ Itt olyan kulturális tartalomról van szó, ami a teljesen automatizált eljárások számára nagyon megnehezíti értelmes kapcsolatok létrehozását. Az értelmes keresés technikái is ki fognak azonban fejlődni, mégpedig valószínúleg hamarosan.

* Az itt következô fejtegetés magyarul csak szövegmagyarázattal kiegészítve értelmezhetô: az angol nyelvben a man (többesszámban: men) szó - elsôsorban a hagyományos, történetileg kialakult szóhasználatban - nemcsak férfit, hanem általában embert is jelent (bár az általános értelemben való használatát „szexista" konnotációi miatt ma üldözik). Lásd Henry Beard és Christopher Cerf kitûnô szótárát és kézikönyvét a politikailag helyes nyelvhasználatról (The Official Politically Correct Dictionary and Handbook, HarperCollins, 1992), melynek ajánlása így szól: „For the former Donna Ellen Cooperman, who, after a courageous yearlong battle through the New York State court system, won the right to be known as Donna Ellen Cooperperson". - $A$ ford.

** Az „All men are brothers” biblikus hangzású mondatra a Google 24300 találatot hozott, Mahatma Gandhi híres jelszavától (és önéletrajzi kötetének címétôl) kezdve a kínai bölcseleti és harcmúvészeti iskolákon át a közelmúltban Amerikában óriási kasszasikert aratott, azonos címû filmrôl és annak „The blood of the leopard" címû folytatásáról szóló recenziókig. $A$ ford. 
Tettem továbbá egy utalást Walter Paterra is ebben az esszében, amit szeretnék kiemelni. Az irodalomszakos diákok megértik, de mindenki más számára rejtett marad. A feldolgozott könyv mint portál akkorra fog igazán megérkezni, amikor eljön az az idő, hogy mindenki megtalálja az utalást.

Önmagára visszautaló szövegként ez az esszé olyan átfogó indexeket nyújthatna, amelyek jelenleg nincsenek benne. Azon a segítségen kívül, amit az ilyen indexek az olvasónak adnának, megkönnyítenék a keresőprogramok számára is, hogy megtalálják és besorolják valamilyen kategóriába az esszét, ami viszont potenciálisan több olvasót jelentene, feltéve, hogy megjelenik a világhálón, ami elkerülhetetlenül meg is fog történni. Az önmagára visszautaló szöveg tisztázna továbbá néhány lehetséges zavart is az elôző részben, ahol Harnad, Kay és Nelson nevére utaltam. Eddig még csak Harnadról volt szó, Kay és Nelson még ezután következik. Egy önmagára utaló szöveg lehetôvé tenné az olvasó számára, hogy egyidejúleg lássa a Kay-re és Nelsonra tett valamennyi utalást. Az ilyen szöveg csoportosítaná és összevonná a metaforákat és az információs kategóriákat is. Így például az irodalmi hivatkozások és a számítástechnikai iparra vonatkozó utalások is kiemelhetôk lennének. Valamennyi metakommentárt, amelyekből szintén sok van a szövegben, már nehezebb feladat lenne azonosítani. Hogyan ismerhetné fel egy gép például azt, hogy mikor „mondunk valamit”, illetve mikor „mondunk valamit arról, hogy mondunk valamit”? Lehetséges, hogy az önmagunkra visszautaló kommentárok lesznek a tisztán emberi dolgok utolsó bástyái.

Az önmagára visszautaló szöveg mennyiségi információt is nyújthat. Például egy kiadó barátom megkérdezte, hogy szándékomban áll-e ezt az esszét könyv formában kiadni, ami felvetette a hosszúságának kérdését. A bitek vagy a szavak megszámlálása triviális feladat a gép számára. Noha nem tudom, hogy ezt miért akarná bárki is megtenni, ez a szöveg is sokféle szempontból elemezhetô. Többek között megállapítható, hogy milyen terjedelem jutott az egyes témáknak, milyen gyakran jelennek meg benne irodalmi utalások, vagy milyen sûrûn fordul elő az idézőjelek és a speciális tipográfiai megoldások alkalmazása.

Az önmagára visszautaló szöveg értéke a mû hosszával arányosan növekszik. Ezt az esszét tekintve az önreferencia nem különösebben feltáró értékú; a Moby Dick esetében azonban lélegzetelállító lenne. Másrészt, ha az esszé piszkozataival kapcsolatban tett valamennyi megjegyzést a szöveg részévé tennénk, akkor az ilyen utalások értékesebbek lennének, mivel nyomon követhetôvvé tennék a gondolatok fejlődését. Ez viszont azt a kérdést veti fel, hogy egy szöveg önreferenciája vajon csak egy bizonyos hálózati csomópontra alkalmazható-e, vagy pedig az egész hálózatra, amelyben „feldolgozottsága” érvényesül.

Igen érdekes lehet továbbá ezt az esszét platformnak tekinteni is. Kis mértékben máris szolgált ilyen minôségben. Egy korábbi olvasója, aki akkor történetesen éppen egy botanikai kézikönyv összeállításán dolgozott, engedélyt kért tôlem, hogy egy bekezdést felhasználhasson: „a könyv mint platform” gondolatát akarta bemutatni az általa szerkesztett kézikönyv szerzóinek. A „feldolgozott könyv” egy részletét „anyagként" kívánta felhasználni a saját munkájához, vagyis platformnak tekintette az eszszét. Nos, ez csupán apró technológiai feladat: mindössze annyit kell tennie, hogy kimásolja a releváns részletet, és beilleszti saját dokumentumába. Ó azonban tudatában volt annak, hogy egy könyv gyakran szerzői joggal védett, és a „cut and paste” eljárásnál többre volt szüksége, hogy az esszét platformként használhassa. 
Ha ez az esszé máris platform lenne, akkor tartalmazna olyan eszközöket, amelyek más íróknak lehetőséget adnak arra, hogy a szöveget vagy egyes részleteit „letöltsék”. Ezek az eszközök szükségképpen tartalmaznák a szerzôi jogra vonatkozó információt, ami nélkül az engedélyek megszerzése sok fáradságba kerülhet. (A szerzói jogok törvényileg elóírt tiszteletben tartásának különféle aspektusai fontosak a téma szempontjából, de itt nem kívánok velük foglalkozni, mert ezek bonyolult kérdések, és bizonyára sok terméketlen vitát sikerülne provokálnom.) Egy jelenleg éppen nem múködő vállalat olyan technikai megoldást alkalmazott, amit valószínûleg sokan utánozni fognak: az általa kiadott múvek szerzői jogaival kapcsolatos tudnivalók megjelentek a képernyőn, ha az olvasó egyszerúen végighúzta az egeret a címeken. Az, hogy milyen szerzői jogi politikát érdemes követni, egyéni megítélés kérdése. Egy író vagy egy kiadó dönthet úgy, hogy szilárdan ragaszkodik a szerzói jogaihoz és a platform bármilyen célú használatát csak a díjak megfizetése ellenében engedélyezi. A szerzői joggal összefüggő kérdéseket - a használat mértékétől és jellegétôl függően - lehet bonyolultabb mátrix szerint is szabályozni: ingyenes hozzáférés az iskolák számára, költséges használati feltételek a nagyvállalatoknak, és így tovább. Egyébként pedig a mú közzétételéhez rendelkezésünkre áll a legegyszerúbb megoldást jelentô, mindenki számára szabadon hozzáférhetố nyilvános szféra (public domain) is.

Hal Abelson és Lawrence Lessig Creative Commons elnevezésû közszolgálati szervezete rendkívül érdekes munkát végez ezen a téren. A Creative Commons egyebek között a nyilvános szféra „felcímkézését”, vagyis különféle jelzések bevezetését javasolja a felhasználók tájékoztatására a közzétett információk jogvédettségi státusáról. E program részeként a szerzói jogi szerződések alapmintáinak sorozatát fejlesztik ki, amelyek lehetővé teszik a szellemi alkotások tulajdonosai számára saját műveik jogvédettségének meghatározását. Ez fontos dolog, ugyanis a Creative Commons múködését megelőzôen az intellektuális tulajdon nagy része vagy birtokosának teljes ellenôrzése alatt állt, vagy pedig a nyilvános szférában foglalt helyet, s így egyáltalán nem állt ellenốrzés alatt. A Creative Commons által kidolgozott szerződések ennek az esszének a szerzôjeként lehetôvé tennék számomra, hogy közbülsố álláspontot foglaljak el. Fenntarthatnám a jogot az esszé mindenféle kereskedelmi felhasználására (ami nem lenne sok és nem érne sokat), de azt is kiköthetném, hogy a nem-kereskedelmi felhasználáshoz nincs szükség sem díjakra, sem engedélyekre. Ha ez egy regény lenne, ragaszkodhatnék ahhoz, hogy mindent védettnek nyilvánítsak benne, de a szereplőket szabadon vagy némi díj ellenében mások számára is elérhetővé tehetném, hogy további múvek származhassanak belőle.

Itt az a lényeg, hogy amikor egy feldolgozott könyvre gondolunk, nem csupán azzal a kérdéssel kerülünk szembe, hogy a technológia segítségével mit tehetünk a tartalommal, hanem a mûveket körülvevô társadalmi és jogi kérdések egész halmazával is foglalkoznunk kell. A társadalmi és üzleti szabályok a technológia eszközeivel kódolhatók és példákkal szemléltethetôk. Ha ez megtörténik, akkor az olvasó vagy a felhasználó ezekre a szabályokra támaszkodhat, és nem kell többé félnie attól, hogy megsérti valakinek a jogait. A könyvnek mint platformnak több köze lehet a szerzối jogi törvényhez és a marketing-stratégiákhoz, mint a bitekhez és a bájtokhoz.

A könyv mint gépi komponens esetében kezdenek a dolgok valóban érdekessé válni. Akárhogyan is próbálok elrejtőzni, ez az esszé sok mindent elmond rólam. A szavak megválasztása és a szintaxis az enyém, az utalások saját mentális beállítódásom- 
ról árulkodnak. A szavaknak és a gondolatoknak nem kell eredetinek lenniük ahhoz, hogy elmondjanak valamit arról a személyről, aki kifejezésre juttatja ôket. Az a tény például, hogy Borges múveit jobban szeretem, mint Faulkneréit, jóllehet Faulkner bizonyíthatóan jobb író, szintén elmond valamit rólam, bár nem is remélhetem, hogy akár csak egyetlen sort valaha is megírhatok úgy, mint Borges. Végsô soron az ízlésünkön keresztül éppúgy megnyilatkozunk, mint a múveinkben. Marshall McLuhan és Ted Nelson művei éppen annyira részemmé váltak, mint az arról szóló rendkívüli mesék, hogy mit jelent a New Jersey-beli Fort Lee-ben felnôni.* A számítógépek különféle elemzések révén úgy is átalakíthatják ezt az esszét, hogy egyfajta proxy lesz belőle az én számomra, vagyis „A feldolgozott könyv” olyan nyersanyag, amiből egy számítógépi „ügynököt” (agent) lehet létrehozni.**

Mit tehetne meg egy ilyen ügynök? Szinte bármit. Szeretnék egy különféle készségekkel jól felszerelt ügynököt, amely rendszeresen fürkészné az Internetet számomra érdekes dolgok iránt, és ezekből mindjárt ki is szűrne sok mindent. Érdeklődöm például az Internet szerzói jogi kérdései iránt (mint ez az esszé is mutatja), de aligha akarom elolvasni az összes kiáltványt, amit az információ szabadságának hívei megfogalmaznak: egy ilyen ügynök talán megtalálhatná számomra a szerzői jogra vonatkozó releváns információkat, kigyomlálva a hatásvadászó retorikát. Vannak továbbá olyan dolgok, amelyekról esetleg nem is tudom, hogy fontosak számomra. Az ügynök felhasználható lenne ezeknek a megtalálására is, oly módon, hogy azonosítana bizonyos tárgyakat vagy témákat (például a burkolt metaforákat) az írásaimban, és öszszevetné azokat hasonló tárgyakkal, amelyeket különféle szervereken bárhol a világon talál.

A számítógépi ügynökök léte nem újdonság. Az a növekvő kifinomultság tekinthetố újnak, amivel ezeket megépítik, és felhasználási céljaik is folytonosan megújulnak. Minden Internet-felhasználó számára ismerős az a profil-készítési technika, amit az e-kereskedelmi oldalak rendszeresen alkalmaznak, bizonyos fajta felhasználók számára megfogalmazva a kifejezetten számukra ajánlott árucikkek reklámszövegeit. A profilok meghatározására szolgáló ügynökök többsége azonban meglehetôsen ügyetlen módon épül fel. Így például az oly nagyon fontos postai irányítószám valószínúleg mond valamit egy adott háztartás jövedelmérôl, tagjainak képzettségi szintjérôl és emellett még sok más dologról is. Mindannyian tudjuk azonban, hogy az irányítószám-elemzés mennyire tökéletlen. Az én utcámban laknak egyetemi oktatók, a Szilícium-völgyben dolgozó magas beosztású szakemberek, és - szemmel láthatólag néhány new-age háztartás is, amelyekben diákok és korábbi diákok laknak. Ne felejtsük el továbbá az ide áttelepült nyugdíjasokat sem (ez tengerparti város). Ám mit mond ez - kérdezhetné joggal bárki - rólam? Hasonló profilok az emberek írásaiból vett statisztikai kivonatok alapján összeállítva sokkal bensôségesebbek lennének, és felhasználási lehetôségeik érdekesebbnek bizonyulnának, mint annak a meghatározása, hogy vajon milyen digitális kamerát fog valaki valószínúleg megvásárolni.

* Burkolt utalás "Five-Finger Discount (A Crooked Family History)" című regényére. - $A$ ford.

** Proxy-nak a számítástechnikában olyan eszközt neveznek, amely más helyett végez el egy feladatot. Például az úgynevezett "tűzfal-proxy" (firewall proxy) egy gazdagépben (host) tárolt információkat közvetíti a gazdagép helyett. Így a gazdagép nem érhetô el közvetlenül, tehát nem is lehet feltörni. Az "ügynök" (agent) olyan hálózati program, amely egy munkaállomás múködési mutatóit továbbítja a központi hálózatvezérlőhöz. (Forrás: Informatikai szótár, Scriptum.) - $\Lambda$ ford. 
A személyes tartalom felhasználásának egyik izgalmas lehetôsége a spam-szúrốk létrehozása. Paul Graham (lásd http://www.paulgraham.com/spam/html) kidolgozott egy úgynevezett white paper-t a bayesi statisztika alkalmazásáról a kéretlen e-mail távoltartására szolgáló, igen fontos szûrôk kifejlesztésében. Ez a szûrési módszer úgy múködik, hogy a felhasználó először maga dönti el, hogy bejövő́ postájában mi az, ami spam, és mi az, ami nem spam. A szûrő ezután statisztikai kivonatot készít mindkét csoportból, és minden további bejövő e-mailt ezekhez viszonyítva értékel. A módszer jellegzetes vonása, hogy a szûrố annál jobbá válik, minél tovább használjuk. A statisztikai mérés egyre pontosabb lesz, ahogy egyre nagyobb adatbázist építünk ki. Nem nehéz elképzelni hasonló eljárás alkalmazását „a feldolgozott könyv” tartalmára is.

Ha ez az esszé gépi komponenssé válna, az lenne a feladata, hogy virtuális képviselőnk gyanánt múködjön, más szóval a gép lelkévé válna. Az így létrejövő gép mưködésébe emberi kultúra (történetesen az enyém) épülne be, és így a gép „emberszerúbb" módon láthatná el a feladatait. Miért állnánk meg azonban ennél az esszénél? Hozzá tehetnénk az összes e-mailt, amit írok (és ezeknek magas súlyt adhatnánk), mindazokat a web-oldalakat, amelyeket megnézek (alacsonyabb súlyozással, mivel az olvasás nem áll olyan közel a csontjainkhoz, mint az írás), és minden mást is, ami az én személyes kifejeződésem. Ez a feldolgozott könyv végső célja: a robotok egy újabb generációjának tájékoztatása - nem azért, hogy a világot gépiesebbé tegyük, hanem azért, hogy a gépek emberibbé váljanak.

Mostanra már bizonyára világos, hogy „A feldolgozott könyv” hogyan szolgálhatna csomópontként. Ebben a feldolgozás mind a négy másik aspektusa, a könyv mint portál, mint önmagára visszautaló szöveg, mint platform és mint gépi komponens egyaránt szerepet játszik. Mindegyik hozzájárul a hálózat múködéséhez. A szövegmagyarázat valahol a portál és a platform funkciók között foglalna helyet, attól függően, hogy melyik szöveg mutat rá valamire, és melyik az, amelyikre rámutatnak. Más szóval „A feldolgozott könyv" - csakúgy, mint bármely más írott dokumentum - közösséget fejleszt ki maga körül. Az ilyen hálózat viszonylagos mérete az adott könyv fontosságától függ: kis hálózat épülne ki e körül az esszé körül, ám Ted Nelson „Irodalmi gépek" (Literary Machines) címú munkája köré óriási hálózatnak kellene szerveződnie. Érdemes megjegyezni, hogy ilyen hálózat a Literary Machines körül - a mú kiemelkedő fontosságának dacára - eddig még nem épült ki. Majdnem bizonyosra vehető, hogy ez a szerző különc döntésének a következménye, aki maga publikálta mûvét, megakadályozva ezzel, hogy akár csak egy szerény méretû́ kiadóvállalat marketingje is úgymond „bepelenkázza”.

Érdekes marketinggyakorlat lehet, ha elgondoljuk, hogyan építhetnénk ki egy ilyen hálózatot „A feldolgozott könyv” körül. Mindenekelótt nyilvánvaló, hogy a dolgozatot fel kellene tenni egy hálózati szerverre, ahol indexelhetik a keresőrendszerek, amelyek hozzá fogják irányítani a felhasználókat. Terjeszthető lenne továbbá különféle elôzetes publikációs formákban is, amelyek közül néhány óhatatlanul szintén felkerülne a Hálóra (ez máris folyamatban van). Elküldhető e-mail üzenetek mellékleteként számos potenciálisan érdekelt (és nem érdekelt) félhez is. A hozzá vezetô linkek megjelentethetők különféle hírcsoportokban (newsgroups). Ennek a könyvnek, vagy bármely más könyvnek a „hálózati üzemmódban” történő piacra viteléhez csupán hagynunk kell, hogy a hálózat végezze el a munkát. Ez annyit jelent, hogy a szokásos ellenôrzési formákat fellazítjuk. A digitális jogok rendezésére kialakított me- 
chanizmus (digital rights management, DRM) igénybe vétele, amely csökkentheti vagy kiküszöbölheti a digitális művek másolását, jó gazdasági döntés lehet például Steven King vagy John Grisham számára, de az ismeretlen szerző́k - mint például „A feldolgozott könyv" szerzője is - jobban járnak, ha megengedik, hogy munkájukat másolják és terjesszék, sốt, egyes esetekben akár kissé meg is változtassák. Amióta egy barátom feltette ennek az esszének egy korábbi fogalmazványát egy hálózati honlapra, amit két hírcsoportban is felfedeztem, elképesztố mennyiségû levelet kapok vele kapcsolatban. A hálózat működik.

Természetesen nem minden hálózati csomópont teremtetett egyenlőnek. (Képzeljük el egy pillanatra, hogy egy számítógép mit tehetne ezzel a mondattal: azon kívül, hogy azonnal kihozná a gettysburgi beszédre* vonatkozó utalást, ebben az esszében is észrevenné azt a korábbi szakaszt, ahol a „minden ember egyenlônek teremtetett” kifejezés megjelent, majd innen visszalépne oda, hogy „minden ember söpredék", és így tovább. Szegény gép!) A könyv mint hálózat új jelenség, és az ilyen hálózatok kiépülésének inherens szabályait még nem ismerjük. Vajon minden csomópontnak megvan a lehetôsége az egyre növekvố hálózat kiépítésére, vagy egyes csomópontok inkább gátolják, ső́t akár meg is akadályozhatják más csomópontok hálózati törekvéseit, mint ahogyan egy nagy hajó nyomdokhullámai elsimítják az aprócska evezős csónak által vert hullámokat? Jelenleg nem tudjuk erre a választ, ám én úgy vélem, hogy a hálózati világban a nagyok fognak uralomra jutni, és a hangok változatos sokaságát, ami jelenleg jellemzi az Internetet, egyre inkább el fogja nyomni egy maroknyi médiabirodalom harsogása, megakadályozva mindennemú szabályozást. A holnap feldolgozott könyvének éppen úgy meg kell küzdenie a figyelemért, mint a tegnap eredeti könyveinek.

V.

Noha már a bevezetésben említettem, hogy a feldolgozott könyvet nem szabad összetéveszteni a különféle olvasókészülékekkel, hasznos lehet megvizsgálni, hogy a feldolgozott könyv megjelenése hogyan fogja befolyásolni ezeknek a kialakítását.

A feldolgozott könyv fogalma kiegészíti az elektronikus publikációval kapcsolatos olyan elgondolásokat, mint amelyek Alan Kay „Dynabook”-jában és Ted Nelson hipertextjében, illetve információs hálózataiban kifejezésre jutnak. A Dynabook alapvetốen hardver-fogalom, és olyan hordozható, kézben tartható számítógépet jelent, amely a világon fellelhetô összes tudáshoz való hozzáférés eszközéül szolgálhat. Ez nyilvánvalóan különbözik a feldolgozott könyvtôl annyiban, hogy a feldolgozott könyv lényege a digitális formában megjelenő tartalom, nem pedig a hardver, amelynek a létrehozását a mindenütt jelenvaló számítástechnika alakítja. A Dynabook eszméi természetesen már megtalálták az utat a piachoz az úgynevezett digitális személyi aszszisztensek formájában és a mobiltelefonok bizonyos funkcióiban is. Ezek a készülékek - egyebek között - szerepet játszanak a feldolgozott könyv fejlődésében is, és funkcióik az olvasáson vagy a nézegetésen túl kiterjednek a szerkesztésre, a hálózati kapcsolatok létrehozására, valamint a kommunikációra és a közvetítésre is.

* Ismételt utalás Lincoln híres beszédére, amelyben az ,all men are created equal" kitétel szerepelt. - A ford. 
Ted Nelson víziója a nem-lineáris írásról erősen emlékeztet a könyv mint hálózati csomópont fogalmára, bár Nelson végül az elgondolásainak gyakorlati kivitelezésére alkalmas rendszer kiépítése mellett kötelezte el magát, és kevesebb figyelmet fordított a tartalom létrehozására. A feldolgozott könyv megkülönböztető jegyei a következők: a tartalomról szól; a tartalom létrehozásának digitális környezetben bekövetkező változásait jelzi; van üzleti dimenziója is (ki fogja megépíteni ezeket az eszközöket és miért?); és rámutat a szerző fokozódó elidegenedésére saját munkájától, mivel a feldolgozás aktusa arra szolgál, hogy a kreativitás kútfóit elkülönítse az összefoglalás, az indexelés és a kivonatolás tevékenységeitôl, amelyeket az automaták örökölhetnek. Kay és Nelson végső soron humanisták, a feldolgozott könyv azonban posztmodern fejlemény.

Az elektronikus publikáció számos egymással versengố mai víziója közül a nagy médiatársaságok azt kedvelik a legjobban, amelyik az elektronikus kiadványok fizikai megjelenését nagyon hasonlóvá akarja tenni a nyomtatott könyvekéhez, ám a fizikai eszközrendszer költségei nélkül. Erre azt mondom: szép dolog, ha megvalósítható. Az elgondolás hívei rendszerint élénken érdeklődnek olyan kérdések iránt, mint például a szerzői jog védelme, és olyan elektronikus kiadói kezdeményezéseket hajlamosak támogatni, amelyek egyértelmúen tiszteletben tartják a tulajdonjogokat. Ez a jövőkép olyan e-könyvek - ebben az esetben lényegében hardver jellegû̉ készülékek - létrehozását vetíti elénk, amelyek kifejezetten csakis olvasásra szolgáló könyvolvasó berendezések. Itt fontos a „csakis” szó: az olyan e-könyv, ami csupán e-könyv és semmi más, alapvetốen különbözik a digitális mobiltelefontól vagy a személyi számítógéptôl, amelyeknek sokféle alkalmazásuk van. A „csakis” e-könyv különálló készülék. Fontos vonása, hogy nem számítógép-perifériaként mủködik, mivel ez annyit jelentene, hogy a tartalom a számítógép és a periféria közötti továbbítás során átmásolódik, és ha így másolható, akkor másolható sokféle más módon is.

Ez a változat bukásra van ítélve, nem azért, mintha a szerzői jog halott lenne, hanem azért, mert valamennyi ilyen módon kiadott ilyen könyvnek versenyeznie kell majd azokkal a könyvekkel, amelyek a feldolgozott könyv gazdag erőforrásaira támaszkodnak. Az önmagában álló könyv a szó szoros értelmében egyedül marad, miközben a hálózati információk hadseregével kell felvennie a versenyt. Ezzel nem azt akarom mondani, hogy bizonyos egyedi könyvek valami magasabb szempontból megítélve nem jobbak, mint a csomópontként funkcionáló könyvek, ám - nyilvánvaló piaci megfontolások alapján -a kreatív emberek számára az jelenti a valódi kihívást, hogy más emberek figyelmét ráirányítsák a munkájukra. Ez az, amiért a kiadók léteznek, és amiért továbbra is létezni fognak. Hálózati támogatás nélkül a legtöbb könyv el fog veszni az új anyagok óriási áradatában.

Így tehát nem kell számítanunk a csakis olvasásra szánt e-könyvek nagyobb arányú elterjedésére. Ehelyett más számítástechnikai berendezésekhez kapcsolódó olvasó-készülékek fognak kialakulni, ilyenek lesznek például a nagyobb és jobb képernyővel ellátott mobiltelefonok is. A technológia világában ezeket „konvergens” készülékeknek nevezik. Idôvel arra számíthatunk, hogy mindannyian egy (és csakis egy) ilyen készüléket fogunk magunknál hordani, amely többszörös felhasználási célokra szolgál.

Ez kölcsönös engedményekkel járó alkut jelent. Míg a kifejezetten csakis ekönyvek olvasására szolgáló készülékek természetesen optimalizálhatók az olvasás gyakorlatához, a konvergens készülékek senkit sem fognak teljes mértékben kielégí- 
teni. Ennek a jelentôsége abban áll, hogy le fogja lassítani a digitális olvasókészülékek terjedését, mivel bizonyos funkciókhoz a nyomtatás egyszerúen továbbra is jobban meg fog felelni. Bizonyos könyvek - elsôsorban a szépirodalmi mûvek - túlnyomórészt továbbra is papírra nyomtatott formában fognak megjelenni, még akkor is, amikor a nyomtatás világa már zsugorodni kezd. A feldolgozott könyv először a szakirodalmat fogja megtámadni, másodszor pedig a fóiskolai tankönyveket, és csak ezután fogja majd kikezdeni a fogyasztói vagy kereskedelmi kiadóipar határszéleit. A feldolgozott könyv elterjedéséig elég sok lépcsőfokon keresztül vezet az út: sok ember észre sem fogja venni, hogy mi történik, mint ahogyan ma is boldogan és ártatlanul vásárolják a mozifilmek DVD változatait, amelyek mindenféle kiegészítő elemet (például eredetileg kihagyott jeleneteket vagy a rendezővel és a színészekkel készített interjúkat) is tartalmaznak. A feldolgozott könyv szükségképpen el fogja foglalni a helyét a virtuális könyvespolcon, mi pedig a kandalló elốtt fogjuk olvasgatni, miközben genetikusan módosított kutyánk békésen szunyókál mellettünk a párnáján.

$$
\text { Magyar Dóra forditása }
$$

\section{Megjegyzés}

Az esszé egyes részei nem kereskedelmi célokra megoszthatók másokkal, feltéve, hogy minden egyes példány tartalmazza a szerzői jogra vonatkozó teljes információt és a szerző e-mail címét. 